University of Nebraska - Lincoln

DigitalCommons@University of Nebraska - Lincoln

2018

\title{
An approach to hydrogeological modeling of a large system of groundwater-fed lakes and wetlands in the Nebraska Sand Hills, USA
}

Nathan Rossman

Vitaly A. Zlotnik

Clinton Rowe

Follow this and additional works at: https://digitalcommons.unl.edu/geosciencefacpub

Part of the Environmental Sciences Commons, and the Hydrology Commons

This Article is brought to you for free and open access by the Earth and Atmospheric Sciences, Department of at DigitalCommons@University of Nebraska - Lincoln. It has been accepted for inclusion in Papers in the Earth and Atmospheric Sciences by an authorized administrator of DigitalCommons@University of Nebraska - Lincoln. 


\title{
An approach to hydrogeological modeling of a large system of groundwater-fed lakes and wetlands in the Nebraska Sand Hills, USA
}

\author{
Nathan R. Rossman, ${ }^{1,2}$ Vitaly A. Zlotnik, ${ }^{1}$ \& Clinton M. Rowe ${ }^{1}$ \\ 1 Department of Earth and Atmospheric Sciences, University of Nebraska-Lincoln, \\ 126 Bessey Hall, Lincoln, NE 68588, USA \\ 2 HDR, Inc., 8404 Indian Hills Drive, Omaha, NE 68114, USA \\ Corresponding author — Nathan R. Rossman nrossman@huskers.unl.edu; nathan.rossman@hdrinc.com
}

\begin{abstract}
The feasibility of a hydrogeological modeling approach to simulate several thousand shallow groundwater-fed lakes and wetlands without explicitly considering their connection with groundwater is investigated at the regional scale $\left(\sim 40,000 \mathrm{~km}^{2}\right)$ through an application in the semi-arid Nebraska Sand Hills (NSH), USA. Hydraulic heads are compared to local land-surface elevations from a digital elevation model (DEM) within a geographic information system to assess locations of lakes and wetlands. The water bodies are inferred where hydraulic heads exceed, or are above a certain depth below, the land surface. Numbers of lakes and/or wetlands are determined via image cluster analysis applied to the same $30-\mathrm{m}$ grid as the DEM after interpolating both simulated and estimated heads. The regional water-table map was used for groundwater model calibration, considering MODIS-based net groundwater recharge data. Resulting values of simulated total baseflow to interior streams are within 1\% of observed values. Locations, areas, and numbers of simulated lakes and wetlands are compared with Landsat 2005 survey data and with areas of lakes from a 1979-1980 Landsat survey and the National Hydrography Dataset. This simplified process-based modeling approach avoids the need for field-based morphology or water-budget data from individual lakes or wetlands, or determination of lake-groundwater exchanges, yet it
\end{abstract}

Published in Hydrogeology Journal 26 (2018), pp 881-897.

doi 10.1007/s10040-017-1691-0

Copyright (C) 2017 Springer-Verlag GmbH Germany. Used by permission.

Submitted 24 March 2017; accepted 3 November 2017; published 27 November 2017. 
reproduces observed lake-wetland characteristics at regional groundwater management scales. A better understanding of the NSH hydrogeology is attained, and the approach shows promise for use in simulations of groundwater-fed lake and wetland characteristics in other large groundwater systems.

Keywords: Numerical modeling, Wetlands, Groundwater recharge, Geographic information systems, USA

\section{Introduction}

Inland lakes and wetlands in many parts of the world have undergone significant transformations at large spatio-temporal scales (e.g. Junk et al. 2013; Riordan et al. 2006; Smith et al. 2005) -for example, satellitebased evaluations of lake numbers in parts of Mongolia and China (Liu et al. 2013; Tao et al. 2015) show a precipitous drop in lake numbers over the last few decades of $\sim 30-50 \%$ due to human activities and climate change. In light of recent trends, there remains a gap in hydrogeological modeling of future changes to large regions with numerous lakes and wetlands. The list of hydrogeological modeling studies of systems of groundwater-fed lakes or wetlands is rather short (e.g. Ala-aho et al. 2015; Donovan et al. 2002; Lemieux et al. 2008; Feinstein et al. 2010a, b; Urbano et al. 2004; Woldeamlak et al. 2007; Voss and Soliman 2014). Largely, these studies deal with relatively permanent lakes or wetlands in humid climates and simulate fewer than $\sim 50$ water bodies. The major challenge of such studies is emulation of lake processes (with areas $\sim 10^{-2}-10 \mathrm{~km}^{2}$ ) and upscaling to the regional groundwater management scale (with areas $\sim 10^{3}-10^{5} \mathrm{~km}^{2}$ ). Associated limitations include data availability, overall complexity of process representation and model parameterization, difficulty of calibration, and significant computational demands (Beven 2012; Brunner et al. 2012).

At regional scales, data requirements associated with the complexity of surface-water features in integrated groundwater/ surface-water models cannot generally be met in practice, unless coarsely resolved topography/bathymetry is used (Lemieux et al. 2008), making it especially difficult to use these models in regions with strongly varying topography such as dune regions (Klove et al. 2014). However, lake-aquifer systems exhibit similarities in response to climate, groundwater recharge (GR), terrane, and topography at large spatial scales that can become more important than local properties (Haitjema and MitchellBruker 2005; Hunt et al. 2003). In such systems, intra-annual and local 
subtleties of individual lake and wetland dynamics may be of secondary interest when addressing long-term and large-scale environmental threats to lakes and wetlands.

Options of modeling lake-wetland systems at regional groundwater management scales include: (1) integrated groundwater/surface-water models, accounting for bathymetry and lakebed parameters of individual lakes (e.g. HydroGeoSphere, ParFlow, MIKE-SHE, MODHMS); (2) groundwater models capable of lake mass balance calculations and estimation of GR from the vadose zone (e.g. GSFLOW); (3) groundwater flow models with GR as an explicit input (no vadose zone), emphasizing robust accounting of water balance of individual lakes (LAK Package for MODFLOW); (4) groundwater models that avoid water balance of individual lakes but use the fictitious domain method of high hydraulic conductivity cells (Anderson et al. 2015); and (5) the statistical approach that correlates the state of the lake-aquifer system and climate, omitting consideration of hydrogeological processes (Liu and Schwartz 2011, 2014). Commonly, calibration techniques are manual trial-and-error for systems exceeding more than a few lakes or wetlands (e.g. Alaaho et al. 2015; Feinstein et al. 2010a; Voss and Soliman 2014).

The primary objective of this paper is to develop and evaluate feasibility of a simplified modeling approach for systems of thousands of groundwater-fed lakes and wetlands. When the lake depths are $\sim 1 \mathrm{~m}$, stage fluctuations cause lakes to evolve into wetlands that create both technical and data quality issues. The Nebraska Sand Hills (NSH), located in central USA, provides the site for a practical modeling application example. The recent historic locations, numbers, and areas covered by the groundwater-fed lakes and wetlands are estimated by developing a rather simple hydrogeological model application, based on available water levels, GR, aquifer hydraulic properties, and land surface topography. This work extends past modeling efforts undertaken over parts of the NSH with various purposes, areal extents, and complexity (e.g. Ayers 2007; Carney 2008; Chen and Chen 2004; Ginsberg 1987; Luckey and Cannia 2006; Luckey et al. 1986; McLean et al. 1997; Peterson et al. 2008; Stanton et al. 2010); however, none of them had the objective of emulating lake processes to infer lake and wetland areas and numbers.

The proposed modeling approach does not explicitly consider groundwater/surface-water fluxes or water budgets of individual lakes or wetlands. Instead, a geographic information system (GIS) analysis is used 
to compare simulated hydraulic heads and land surface elevations to identify and map water bodies. After calibration, the model will be suitable for predicting the impacts on the lake-wetland-groundwater system caused by long-term land use and/or climate changes, and evaluation of times needed for the system to approach steady state (e.g. RousseauGueutin et al. 2013).

The process of completing the objective involved the following tasks: (1) evaluation of hydraulic head and lake stage (DEM) data validity for model calibration; (2) reconciliation of different spatio-temporal scales in data on GR, transmissivity, head values, land surface elevations, and land cover classifications; and (3) adjustment of available data on stream elevations and leakance, transmissivity, and GR fluxes. With ongoing expansion of data sets collected for different interrelated processes and with various resolutions, such tasks are becoming progressively common for developing regional-scale groundwater flow models.

\section{Study area}

\section{Lakes and wetlands}

The study area in northwestern Nebraska (Fig. 1) covers 39,300 km² of the central and western NSH, the largest dune region in the Western Hemisphere (Ahlbrandt and Fryberger 1980). Abundant marshes and sub-irrigated meadows (wetlands), and small shallow lakes are embedded in the High Plains aquifer (Fig. 2) where the water table intersects the land surface or is close to it in many interdunal depressions (McCarraher 1977; Rundquist 1983). Shallow groundwater sustains the fen ecosystems supporting unique flora and fauna (Harvey et al. 2007) and the beef cattle industry of great economic importance (Bleed and Flowerday 1998). In the current semiarid climate, there are approximately 4,700 distinct water bodies (lakes) and over 2,000 $\mathrm{km}^{2}$ of wetlands (Dappen et al. 2007) adjacent to up to 130-m tall, wind-blown sand dunes stabilized by native grasses (Rundquist 1983). Nearly 75\% of precipitation (430$580 \mathrm{~mm} / \mathrm{yr}$ ) is received from April to September (Bleed and Flowerday 1998). The topography is highly variable because of the sand dunes, but slopes generally from west to east (Fig. 2). The NSH study area has limited irrigation and ecological changes (McGuire 2014) due to high GR rates ( $\sim 13 \%$ of precipitation; Szilagyi et al. 2011 a) compared with many 


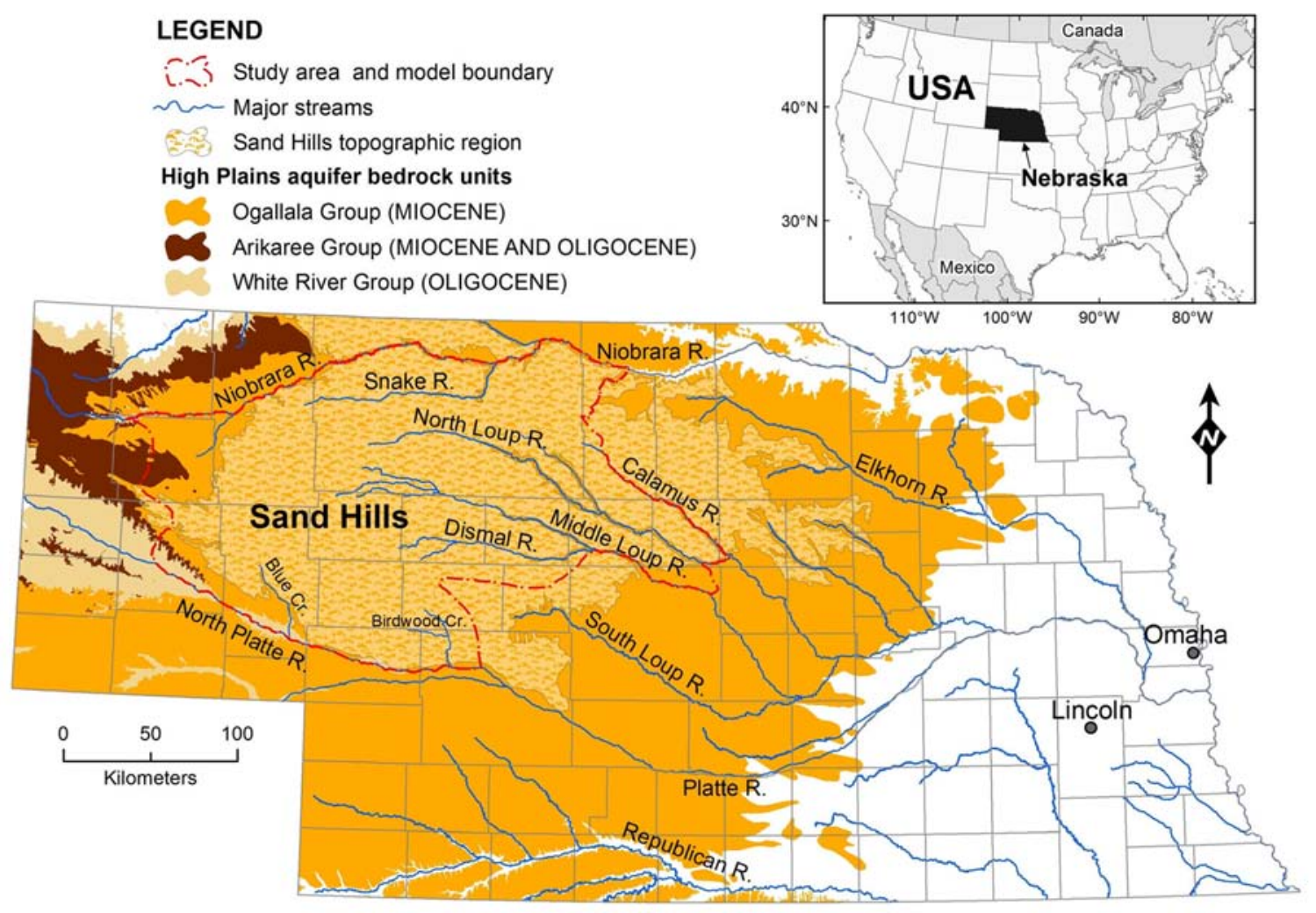

Fig. 1. Location of study area (outlined in red) with location of the Sand Hills topographic region, major streams, and major bedrock units of the High Plains aquifer in Nebraska. Gray lines are county boundaries. Major streams are shown for reference.

other arid or semiarid regions (e.g. Scanlon et al. 2012; Tao et al. 2015). Groundwater pumping is negligible in the study area, except in parts of Box Butte County (west of the Sand Hills boundary; Fig. 2; cf. Fig. 6 in Szilagyi et al. 2011a).

Lakes are most common in the western "closed-basins area" where stream drainages have been dammed by dune migration in the early Holocene (Loope et al. 1995) and where the water-table gradient is shallow due to land uplift (Bleed and Flowerday 1998). Most of the lakes do not have surface inlets or outlets (Winter 1986), evaporation from them greatly exceeds precipitation (Winter 1986, 1990), and lake levels are generally lower than the regional potentiometric surface (Ong 2010; Winter 1986), as is typical for groundwater-fed lakes (Zlotnik et al. 2009), providing evidence that the lakes act as areas of focused groundwater discharge and high evapotranspiration (ET). 


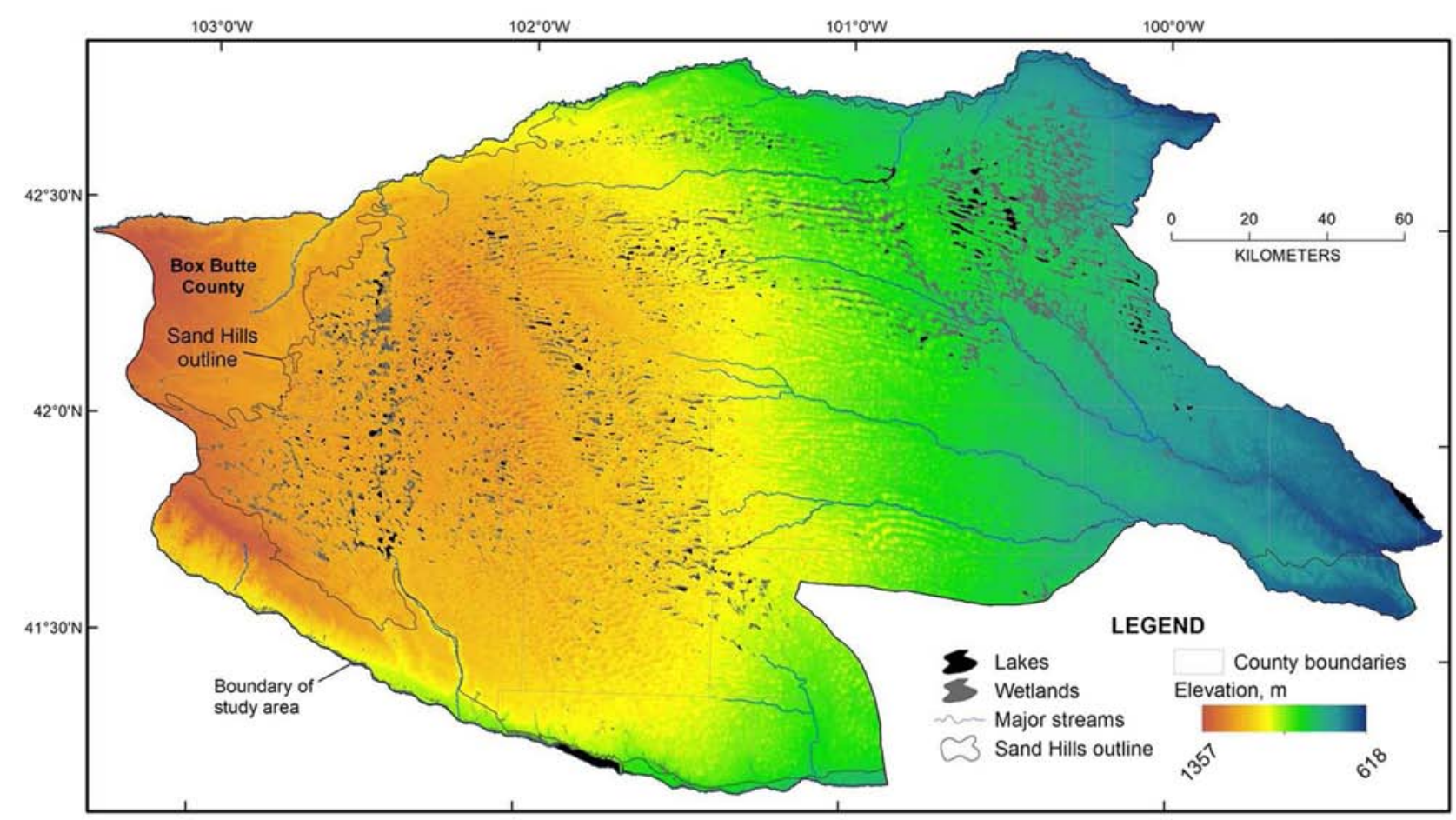

Fig. 2. Topography of the land surface, lakes, wetlands and major streams, and the outline of the Sand Hills topographic region within the study area. Box Butte County is also labeled.

Most lakes are small, only a few tens of hectares, but some are larger than $5 \mathrm{~km}^{2}$ (Bleed and Flowerday 1998). Lakes are shallow in the NSH (mean depth $\sim 0.8 \mathrm{~m}$ ) and dynamic seasonally, annually, and over geologic time, due to their shallow depths (Gosselin et al. 2000; McCarraher 1977). Surveys of the total area covered by natural lakes in the NSH range from about $349 \mathrm{~km}^{2}$ (Dappen et al. 2007) to $455 \mathrm{~km}^{2}$ (Rundquist 1983) - depending on the methods used, season, and year of survey due to the influence of weather and climate-indicating variability of lake and wetland areas of roughly $25 \%$.

The map of the regional water table, based on spring 1995 measurements from wells screened in the High Plains aquifer and elevations of surface water features (streams, lakes, and wetlands) from 7.5-min US Geological Survey (USGS) topographic maps (Summerside et al. 2001), provides the basis for understanding flow directions and areas of recharge and discharge. Streams almost entirely act as discharge points for the groundwater system, and a large area with a shallow water table occurs in the west-central part of the study area, forming a wide saddle 


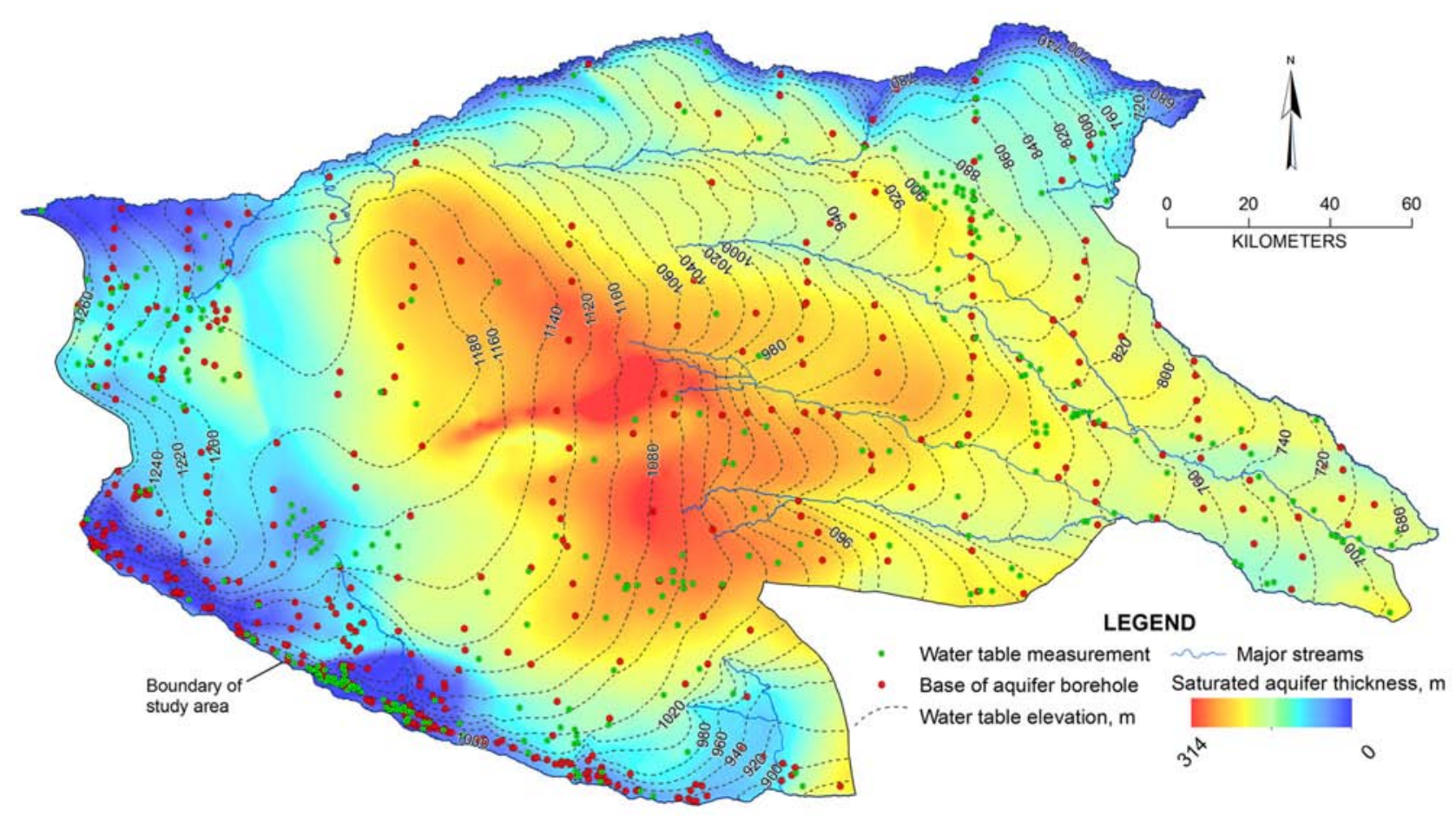

Fig. 3. Saturated aquifer thickness (color shaded) and water-table topography from 1995 (20-m contours), including the water-table measurement wells and base-of-aquifer boreholes.

directly to the west of it (Fig. 3). The major rivers on the north and south boundaries of the model originate outside of the study area, while the other rivers have headwaters within the NSH (Fig. 1). Estimated longterm (10 years) total baseflow from all six major streams exiting the model domain equals $4.185 \times 10^{6} \mathrm{~m}^{3} / \mathrm{d}$, based on streamflow gauge records (see Fig. 4a for locations and the electronic supplementary material (Supplementary Materials) for methods used to estimate baseflow, and see Table $\mathbf{S 1}$ of the Supplementary Materials for gauge data and baseflow estimates).

\section{Geology and hydrostratigraphy}

The High Plains aquifer is primarily composed of Miocene Ogallala Group fine-to-medium sand and sandstone (Korus et al. 2011). The Oligocene and Miocene Arikaree Group, comprised of sandstone and siltstone, is an important part of the High Plains aquifer in western Nebraska, covering parts of the western third of the NSH, and some local paleovalleys in 


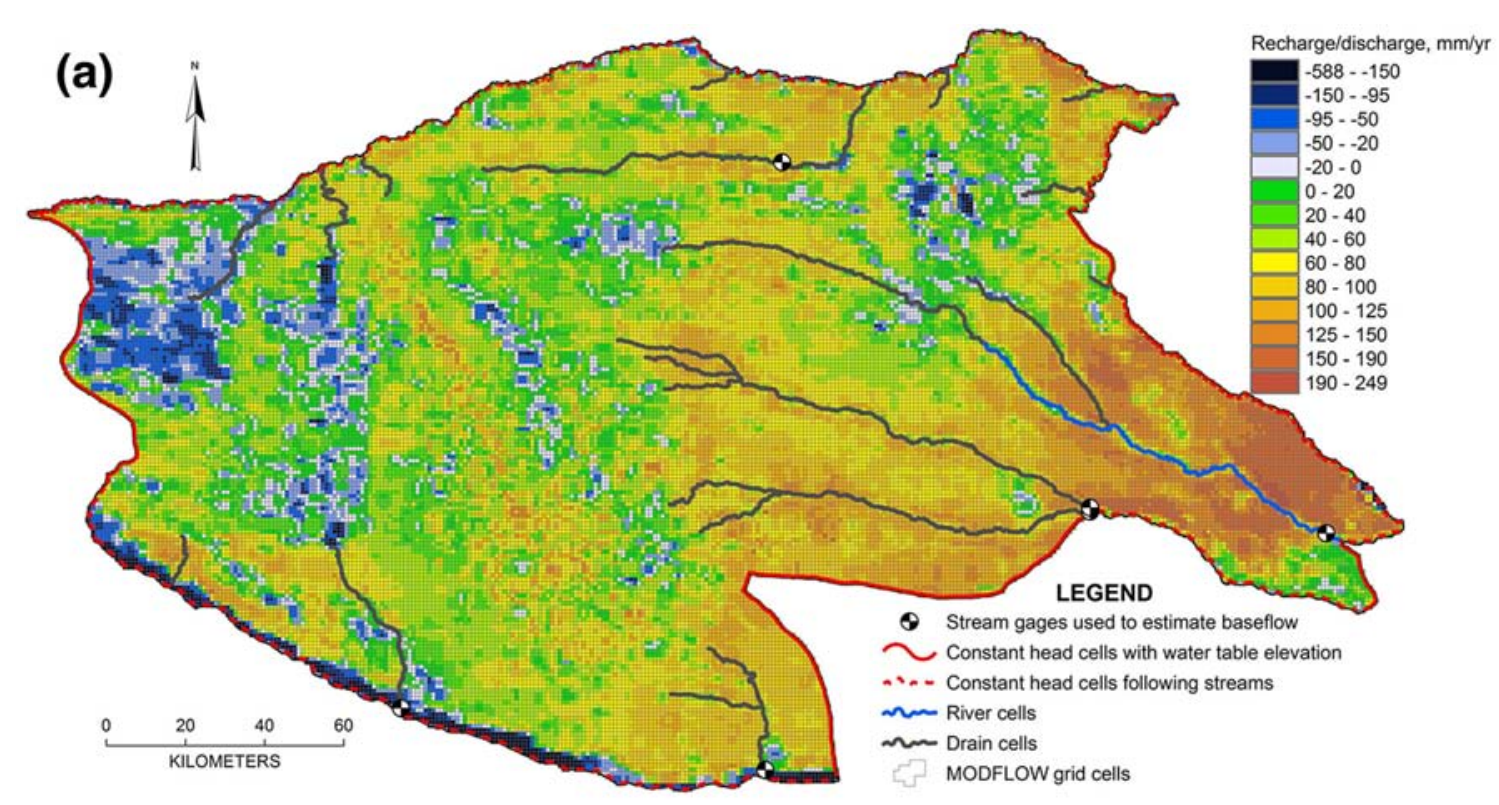

(b)

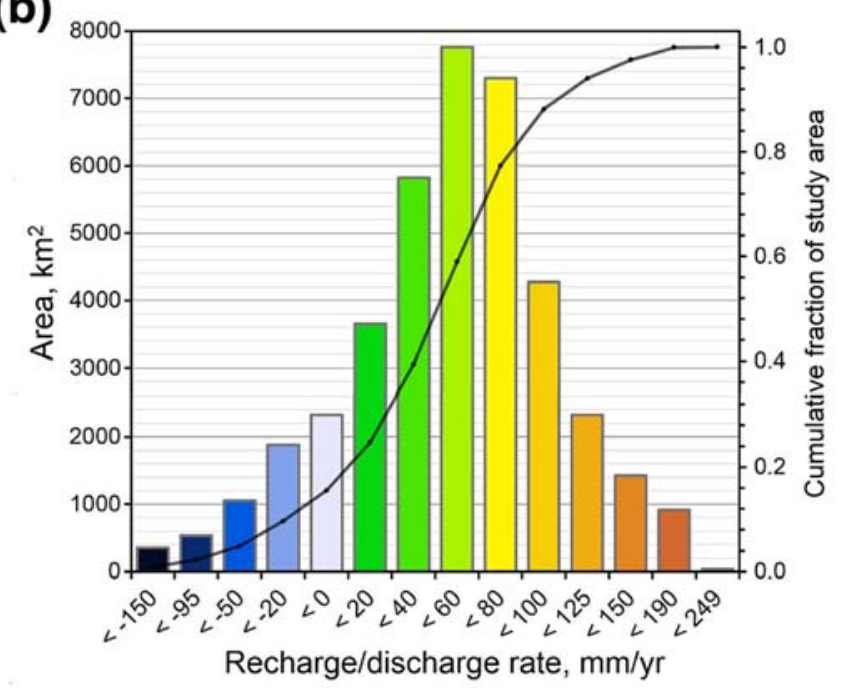

Fig. 4. Mean net groundwater recharge flux to/from the water table from 2000 to 2009, from the difference between $P$ and satellite-derived ET (MODIS), created using data published in Szilagyi and Jozsa (2013): a) spatial distribution and magnitude of fluxes (mm/yr), stream gauges used to estimate baseflow, model (MODFLOW) grid cells (1$\mathrm{km}$ ), and boundary conditions for the finite-difference model; and b) histogram and cumulative frequency of net groundwater recharge fluxes. Blue colors represent areas of net groundwater discharge (ET $>P$ ), and other colors represent areas of net groundwater recharge $(P>E T)$. Note the nonlinear scale of the horizontal axis. 
other parts of the region (Bleed and Flowerday 1998; Korus et al. 2011). Pliocene alluvial sands and gravels, and Holocene eolian dune sands, comprise the uppermost portion of the High Plains aquifer; in the uplands, these uppermost units are mostly unsaturated (Korus et al. 2011). Generalized geologic and hydrostratigraphic frameworks and cross-sections of Nebraska are presented by Bleed and Flowerday (1998) and Korus et al. (2013). The unconfined aquifer exhibits minimal contrasts of hydraulic conductivity $(K)$ between hydrostratigraphic units, sufficient to simulate the regional flows as two-dimensional (2D), which is common practice for models simulating flow in the High Plains aquifer. Previous modeling studies have successfully calibrated and applied single-layer regional models for various purposes in the NSH (e.g. Luckey and Cannia 2006; Luckey et al. 1986; Peterson et al. 2008; Stanton et al. 2010).

The base of the aquifer generally coincides with the base of the Ogallala Group and the top of the Cretaceous Pierre shale (Bleed and Flowerday 1998); however, along western parts of the NSH, the base of the aquifer is in the Arikaree Group siltstone, and in a small region along the North Platte River, it is in the Brule Formation of the White River Group siltstone. These basal units are poorly permeable and considered to have negligible flow (Chen and Chen 2004; Peterson et al. 2008).

\section{Groundwater flow modeling}

\section{Description of data}

Several published data sets collected by the USGS, units of the University of Nebraska-Lincoln (UNL) - including the Conservation and Survey Division (CSD) and Center for Advanced Land Management Information Technologies (CALMIT) - and the Nebraska Department of Natural Resources (NDNR), are available for construction, calibration, and assessment of the performance of groundwater flow model simulations in the NSH. Data sets include: (1) regional water table contour map; (2) digital elevation model (DEM) of land surface elevations; (3) base of the principal aquifer contour map; (4) hydraulic conductivity estimates from the statewide test-hole data base; (5) spatially distributed net groundwater recharge $\left(\mathrm{GR}_{\mathrm{n}}\right)$ from remote sensing estimates (MODIS-based ET); (6) land-cover map based on Landsat 5 Thematic Mapper satellite imagery; 
and (7) streamflow gauge data for baseflow estimates. Further detailed information about these data sets and their sources is provided in section S1 of the Supplementary Materials.

\section{Conceptual model}

The majority of model lateral boundaries (Figs. 1 and 2) follow streams and major rivers. The ground surface elevations are based on $10-\mathrm{m}$ resolution National Elevation Dataset (NED) DEM data from USGS. The bottom elevations are from an interpolation of the elevation contours of the base of the principal aquifer (empirical Bayesian kriging method with ArcGIS). Elevations of the top and bottom of the domain were aggregated to 250-m resolution and used to determine aquifer thickness (Fig. 3). Saturated aquifer thickness ranges from near zero-where aquifer units pinch out along parts of the northern and southern margins of the study area at the Niobrara and North Platte River valleys (Fig. 1) - to $314 \mathrm{~m}$ in the central part of the domain, and averages $161 \mathrm{~m}$.

As shown by other regional models covering the NSH (e.g. Chen and Chen 2004; Stanton et al. 2010), the water budget flow components are dominated by diffuse GR, discharge to streams as baseflow, and underflows with parts of the unconfined High Plains aquifer outside of the model. Currently, the average $\mathrm{GR}_{\mathrm{n}}$ rates in the NSH is about $70 \mathrm{~mm}$ ( $\sim 13 \%$ of precipitation), exceeding $200 \mathrm{~mm}$ in a few areas ( $\sim 37 \%$ of precipitation; Szilagyi et al. 2011a). The MODIS-based spatial average of $\mathrm{GR}_{\mathrm{n}}$ over the selected (smaller)model domain equals $46 \mathrm{~mm} / \mathrm{yr}$, representing an inflow of $4.96 \times 10^{6} \mathrm{~m}^{3} / \mathrm{d}$. This is expected to represent a large majority of inflows to the aquifer system, dwarfing underflow and stream leakage to the aquifer.

\section{Discretization}

A uniform $192 \times 348$ grid with 1-km horizontal dimensions of the grid cells, consistent with the $\mathrm{GR}_{\mathrm{n}}$ map resolution $(1 \times 1 \mathrm{~km}$; Fig. $4 \mathrm{a})$, was used. Information about vertical variations in lithology permitted the simplest one-layer vertical discretization (sections "Geology and hydrostratigraphy" and "Description of data"). Early testing of three and five layers had minor impacts on the flow field and head gradients, so a single layer model was retained. The final grid design included 39,640 active grid cells. Using Visual MODFLOW Flex (VMF; v. 2014.2) parameters 
were transferred to the finite-difference grid, and simulations were performed with MODFLOW-2005 and PEST (Parameter ESTimation). Simulation results were processed in ArcGIS (v. 10.2) and MATLAB (R2012b). The simulation was performed assuming steady-state conditions, rather than transient, for the following reasons:

1. Changes in water-table elevations in the NSH were minor with minor spatio-temporal trends $(< \pm 2 \mathrm{~m})$ since predevelopment, and from 2001 to 2011 (Korus et al. 2011; McGuire 2014).

2. Minimal groundwater pumping occurs in the $\mathrm{NSH}-$ only about $4 \%$ of the total area is irrigated (Sridhar et al. 2006).

3. Streamflows of the Dismal River, representative of the NSH headwater streams, were nearly identical in 1995 as they were from 2000 through 2009 , as evidenced by the USGS stream gauge data; these are the two time periods in which calibration targets (heads) and hydrologic stress $\left(\mathrm{GR}_{\mathrm{n}}\right)$, respectively, were available.

4. The choice to develop a steady-state simulation relies on $\mathrm{GR}_{\mathrm{n}}$ estimates derived from MODIS satellite temperature measurements (Szilagyi and Jozsa 2013; Szilagyi et al. 2011b) that are also based on steady-state assumptions for vadose zone fluxes (see section S1 of the Supplementary Materials). Rossman et al. (2014) showed that this assumption holds for time-scales of $\sim 5-10$ years for the NSH.

\section{Boundary conditions, water sources and sinks}

The model base is assigned a zero-flow boundary, as the formations underlying the principal aquifer are poorly permeable. Major streams provide accurate and minimally changing estimates of hydraulic head, so they were modeled using the Constant Head package, including the streams along the northern, southern, and eastern parts of the domain (Fig. 4a). These boundaries are located far from areas of interest in central portions of the domain - areas that control the overall water balance, as can be verified by comparison with baseflows to internal streams (gauge locations shown on Fig. 4a). The boundary in the southeastern part of the domain has been selected to correspond closely with stream gauges for ease of comparing simulated and estimated baseflow rates. Major streams and other lateral boundaries of the model in the upland areas were assigned Constant Head elevations based on the interpolated 
1995 regional water-table map (Figs. 1 and 4a for locations), except for the North Platte River where elevations were assigned using the minimum DEM elevation within the model grid cells.

The western boundary was extended beyond the Sand Hills boundary to minimize artificial boundary effects, requiring the inclusion of most of Box Butte County, where the water table is in decline (Korus et al. 2011). Although there are densely spaced irrigation wells in this county (Fig. 2), after approximately 70 years of large-scale groundwater pumping, there has been no detection of effects to the water table in the Sand Hills region (e.g. Ayers 2007; Korus et al. 2011; McGuire 2014). Diffuse GR from precipitation $(P)$, and losses from the groundwater system caused by groundwater ET from native and afforested vegetation, evaporation from lakes and open water, and groundwater pumping, are sources/sinks in the one-layer model through application of positive and negative MODIS-based $\mathrm{GR}_{\mathrm{n}}$ rates. Based on 2000-2009 P-ET estimates (Fig. 4a), net groundwater discharge (negative $\mathrm{GR}_{\mathrm{n}}$ ) occurs in $15.5 \%$ of the model grid cells (Fig. 4b).

\section{Interior streams}

The specification of boundary conditions along interior streams is consistent with the 1995 regional water-table map and other stream-aquifer interaction studies in the NSH (e.g. Chen and Chen 2004; Chen et al. 2003; Stanton et al. 2010). Stream locations and length of stream segments within each MODFLOW grid cell are from the high-resolution USGS National Hydrography Dataset (NHD; NDNR 2016). Streams located in the interior of the model (Fig. 4a) were simulated with the Drain and River package. Drain boundary conditions only allow the streams to remove water from the aquifer-an appropriate conceptualization for sand dune areas, where overland flow is small relative to infiltration (Bleed and Flowerday 1998). The only stream in which the River Package was applied was on the North Loup River due to its relatively high streamflow and relatively low baseflow index (Table S1 of the Supplementary Materials), allowing for the river to recharge the aquifer in sections where the specified river stage is higher than simulated aquifer heads.

River stage and drain boundary elevations were assigned using the minimum DEM value within a given model grid cell with river bottom elevations assumed as $1 \mathrm{~m}$ below stage. Initial linear leakance values (conductance of streambed materials per unit length within a grid cell) 
were based on USGS modeling studies covering the eastern half of the study area (Peterson et al. 2008; Stanton et al. 2010).

\section{Lakes and wetlands}

Groundwater-fed lakes and wetlands constitute just a thin sliver on the land surface in spite of their large quantity and areal coverage. Their numbers and areas, modulated by groundwater conditions, smoothly fluctuate under the current climate and land use conditions, as evidenced by Landsat surveys (Dappen et al. 2007; Rundquist 1983) and the NHD, as well as maps of groundwater level changes (McGuire 2014). At the same time, thousands of individual lake depth records and bathymetry are unlikely to be available in the foreseeable future even with progress in remote sensing.

The groundwater model is used to simulate hydraulic heads that are then used to infer position of lakes and wetlands by comparing to the local land surface topography (from the DEM). Areas with a shallow water-table elevation are proxies for landscape positions where groundwater discharge to depressions is likely to occur and groundwater-fed lakes and wetlands should be found (cf. Zlotnik et al. 2009). The hydraulic heads from the 1995 regional water-table map, and those simulated with the groundwater model, were resampled (bi-linearly in ArcGIS) to the same $30-\mathrm{m}$ resolution as the 2005 Landsat land cover map before being mapped and analyzed for total lake and wetland characteristics. Next, water table depth was calculated as the difference between DEM elevations (aggregated to the 30-m grid) and hydraulic heads. Those locations where the regional water table is above the local land surface were classified as (groundwater-fed) lakes-being consistent with the use of a 1-km grid spacing, the regional water-table map-contour interval of $50 \mathrm{ft}(15.24 \mathrm{~m})$ - and the variable topography of the NSH region. Areas where the water table is less than $3 \mathrm{~m}$ deep were classified as wetlands, consistent with the extinction depth of ET of 2-5 m, representative of the NSH (Szilagyi et al. 2013). More importantly, it produced the best match with observed lakes and wetlands in the 2005 Landsat survey (Dappen et al. 2007); depths of 4-5 m were also analyzed.

Total areas of lakes and wetlands within the Sand Hills region were quantified by multiplying the number of $30-\mathrm{m}$ pixels in each class by their area. The total number of lakes and numbers of combined lakewetland complexes were quantified in MATLAB, where the built-in 
"bwconncomp" function (cluster analysis script) was used to determine the number of connected components (connected 30-m grid pixels); an 8-connected neighborhood was used. A flowchart (Fig. S1 of the Supplementary Materials) provides the processing steps taken to quantify and map areas and numbers of lakes and wetlands. These features were mapped across the entire study area, but the characteristics of total areas and numbers were only quantified within the NSH portion of the study area assessed (Sand Hills region excluding a 1-km buffer area around major rivers; covering $32,122 \mathrm{~km}^{2}$ ). Note that determination of the number of wetlands separate from lakes was not possible since many wetlands are fringing lakes, and therefore grade from one land use class to another.

\section{Feasibility of approach}

Among all variety of process-based models, only the least data-demanding and simplest models were feasible. Even the relatively simple fictitious domain (or high- $K$ ) approach needs 3-D lake bathymetry and aquifer properties near individual lakes and wetlands that are typically unavailable. Here, a single-layer model, emphasizing long-term remotely sensed $\mathrm{GR}_{\mathrm{n}}$ estimates to constrain calibration, was used.

This approach can be immediately tested by comparing delineated lakes and wetlands in the NSH with available observations, in this case the 2005 Landsat survey (Dappen et al. 2007). A successful match indicates that when process-based models can reproduce the water-table map (head targets) they can also match overall areas and numbers of observed lakes and wetlands without explicit consideration of them individually in the model formulation. This approach has not been explored previously at regional scales. Following the above procedure, a total area covered by lakes and wetlands of $2,104 \mathrm{~km}^{2}$ (6.55\% of area assessed) was obtained using the interpolated 1995 regional water-table map (Topo to Raster geoprocessing tool in ArcGIS), which compares favorably with the 2005 Landsat survey of Dappen et al. (2007; Fig. 5a,b), where total area of lakes and wetlands is $1,879 \mathrm{~km}^{2}(5.85 \%$ of area assessed). The comparison is encouraging, especially considering the uncertainty of total areas from Landsat surveys.

In the process of inferring lakes and wetlands from the regional water-table map, some areas were found where the water table was greater than the DEM elevation, but lakes were not present in the 2005 Landsat 

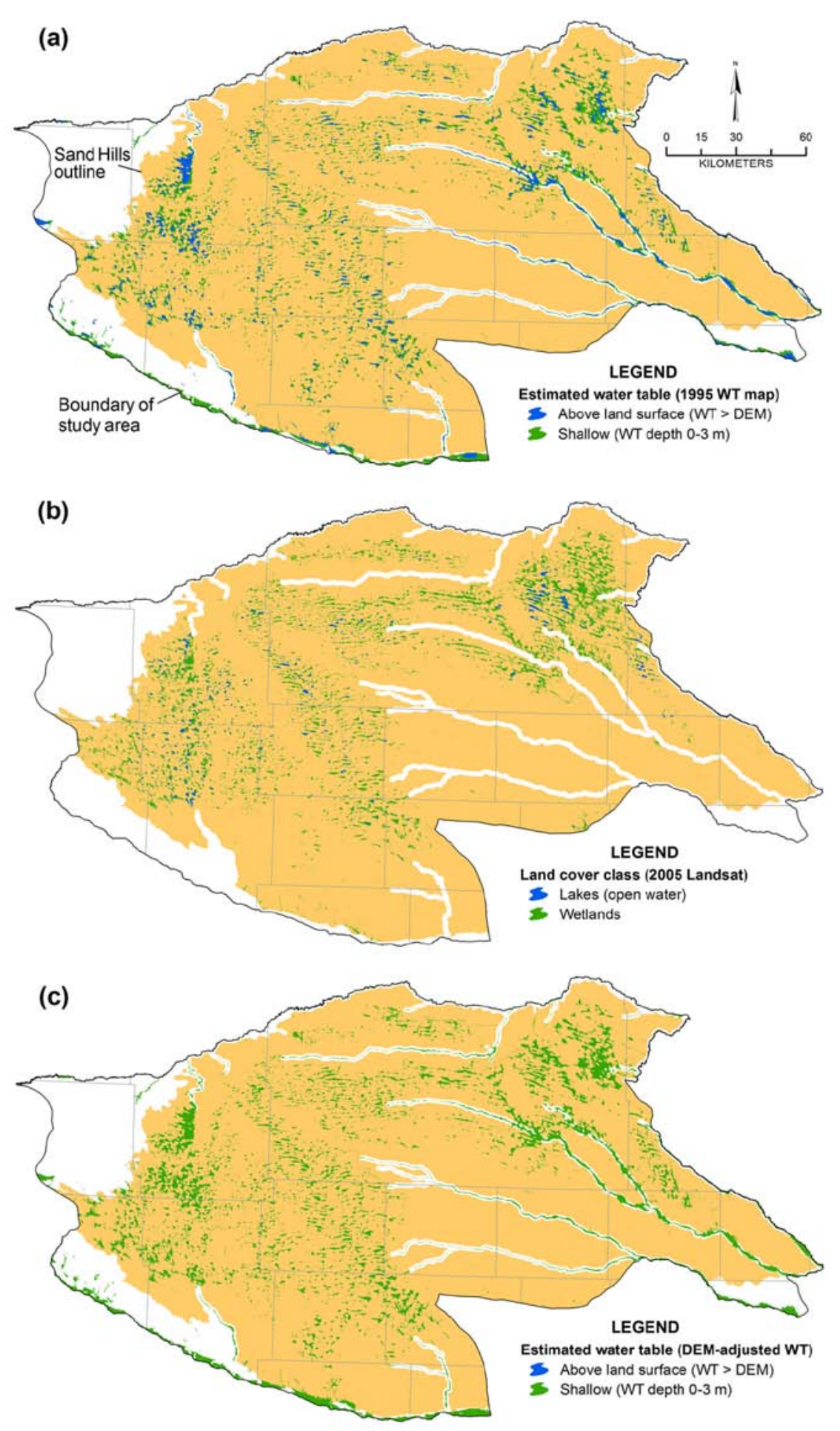

Fig. 5. Spatial distribution of lakes and wetlands in the study area and Sand Hills region: a) estimated using elevations from the 1995 regional water-table (WT) map; b) observed from the 2005 Landsat land cover survey of CALMIT (Dappen et al. 2007); and c) estimated using DEM-adjusted 1995 regional water table elevations (the source of hydraulic head calibration targets). 
survey (Dappen et al. 2007), as well as other areas in which water-table elevations were lower than the DEM elevations where lakes were present in the 2005 Landsat survey (Fig. 5). Therefore, in these areas of bias, the interpolated 1995 regional water-table elevations were slightly adjusted by substituting DEM elevations (lake stage or land surface elevation) for the water-table elevations. Since lakes are inferred where the water table is above the local land surface, and the DEM elevations were used to replace the interpolated regional water-table elevations, this processing step effectively removed lakes and only results in wetlands being mapped (Fig. 5c). With this correction, total area of lakes and wetlands obtained equal 2,147 $\mathrm{km}^{2}(6.68 \%$ of area assessed).

\section{Model calibration}

Initial simulations using parameters based on existing models and available data $\left(K, \mathrm{GR}_{\mathrm{n}}\right.$, stream leakance and stage) indicated the need for adjustments to the model. Analyzing feasibility of calibration of large-scale steady-state models, Knowling and Werner (2016) discussed tradeoffs between constraining recharge versus constraining $K$ distributions. In the study reported in this paper, the recharge distribution data obtained from remote sensing are treated as having a higher degree of information content than the $K$ parameter because each grid cell $(39,640)$ has a $\mathrm{GR}_{\mathrm{n}}$ estimate from remote sensing, whereas the basic $K$ data are limited to 261 thickness-weighted average estimates (one observation in every $\sim 152 \mathrm{~km}^{2}$ ).

Manual and automatic calibration techniques were used in an effort to minimize differences (residuals) between simulated and observed (estimated) hydraulic heads. Calibration was considered complete if the root mean square error (RMSE) was less than the maximum potential error in water-table elevations, about one-half of the contour interval (7.6 m), with a smaller mean error (ME). Visual match with the 1995 water-table contour map was also used to evaluate the calibration. In addition, calibration was assessed by comparing total simulated net outflow with observation-based baseflows of interior streams, and simulated and interpreted lake and wetland areas and numbers were compared with the 2005 Landsat land cover survey. However, the observed total baseflow from gauges and the land cover classes were not formally a part of the objective function. 
The model calibration involved six key steps-Table S2 of the Supplementary Materials lists the order of calibration steps and provides condensed descriptions. For brevity, only the most important steps involved in the calibration approach and the results from assessment of the calibration performance are presented in this section. Readers interested in further details of model calibration are encouraged to read section S3 of the Supplementary Materials.

After substituting DEM elevations for water-table elevations from the 1995 water-table map (Fig. 5c), average water-table elevations within each grid cell (aggregated from 30-m to 1-km resolution) were calculated for use as quantitative calibration targets. Grid cells used as targets were those containing: (1) observed lakes; (2) observed wetlands, either type having an area greater than 10 ha based on the 2005 Landsat survey; (3) wells with 1995 water-table measurements; or (4) evenly spaced grid cells at $10 \mathrm{~km}$ (every other pilot point). This resulted in a total of 7,937 grid cells with head targets (20\% of active cells), a majority containing lakes $(1,457)$ and wetlands $(6,035$; Fig. S3b of the Supplementary Materials). Targets were assigned weights $(1.5,1.3,1.1$, and 1.0, for grid cells containing lakes, wetlands, water-table measurements, and pilot points, respectively) in PEST according to their perceived importance and accuracy.

The pilot point method (Doherty et al. 2010) was used to perform PEST optimization of $K$. Two PEST runs were performed, one with original MODIS-based GR $\mathrm{n}_{\mathrm{n}}$ (from Szilagyi and Jozsa 2013), and one after manual adjustment of $\mathrm{GR}_{\mathrm{n}}$. The $\mathrm{GR}_{\mathrm{n}}$ estimates greatly constrained the calibration process, and the manual adjustments made were not dramatic (maximum changes of $20 \mathrm{~mm} / \mathrm{yr}$ ). All adjustments to $\mathrm{GR}_{\mathrm{n}}$ were lower than the expected error, which is at least $60 \mathrm{~mm} / \mathrm{yr}$ (at the MODIS pixel scale) in the NSH, considering an error range of about $5 \%$ in $P$, and $10 \%$ in ET, and that $P$ and ET are each no lower than $\sim 400 \mathrm{~mm} / \mathrm{yr}$ (Szilagyi et al. 2011a). The relatively small changes made to $G_{n}$ indicate a high level of reliability of the original $\mathrm{GR}_{\mathrm{n}}$ estimates, especially considering the large uncertainty typical of GR estimation methods (Healy 2010). The final PEST run on $K$ was performed using a Tikhonov-regularization process to constrain the inversion (Tikhonov and Arsenin 1977) and the lower and upper limits to $K$ of 1 and $36 \mathrm{~m} / \mathrm{d}$ were applied, as well as the adjusted $\mathrm{GR}_{\mathrm{n}}$ values. Initial $K$ values were those assigned as means to 29 zones based on borehole lithology (Fig. S2 of the Supplementary Materials). 


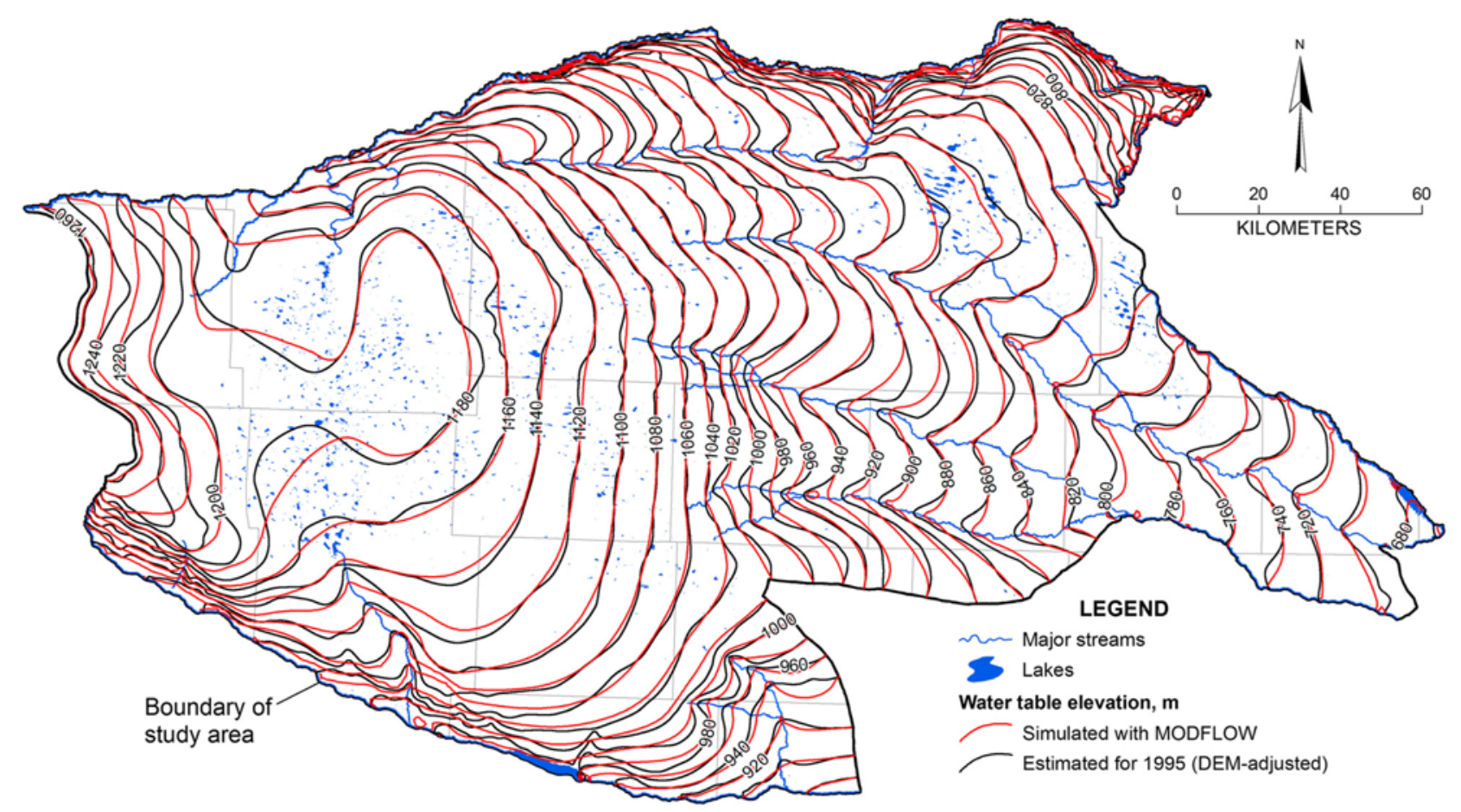

Fig. 6. Comparison of simulated (calibrated) and estimated hydraulic head contours based on interpolated DEM-adjusted 1995 regional water-table elevations. The contour interval is $20 \mathrm{~m}$. Lakes and major streams are shown for reference.

Hydraulic head contours from the calibrated MODFLOW simulation were compared with the interpreted heads-interpolated 1995 watertable contours (with some DEM-substituted elevations) as shown on Fig. 6. The ME equaled $-0.23 \mathrm{~m}$, and the RMSE equaled $2.8 \mathrm{~m}$. Absolute head residuals of less than $5 \mathrm{~m}$ accounted for $92.9 \%$ of the targets, and $61.1 \%$ were less than $2 \mathrm{~m}$. Graphical comparisons of simulated heads, head residuals, and head targets, are shown on Fig. 7. All of these results demonstrate limited spatial and topographic bias, and a reasonable calibration meeting the established criteria.

\section{Results}

\section{Groundwater recharge and hydraulic conductivity}

The spatial average of calibrated $\mathrm{GR}_{\mathrm{n}}$ values equaled $52.6 \mathrm{~mm} / \mathrm{yr}$, an increase by $6.6 \mathrm{~mm} / \mathrm{yr}$ (14.3\%) over the original average of $46 \mathrm{~mm} / \mathrm{yr}$; 


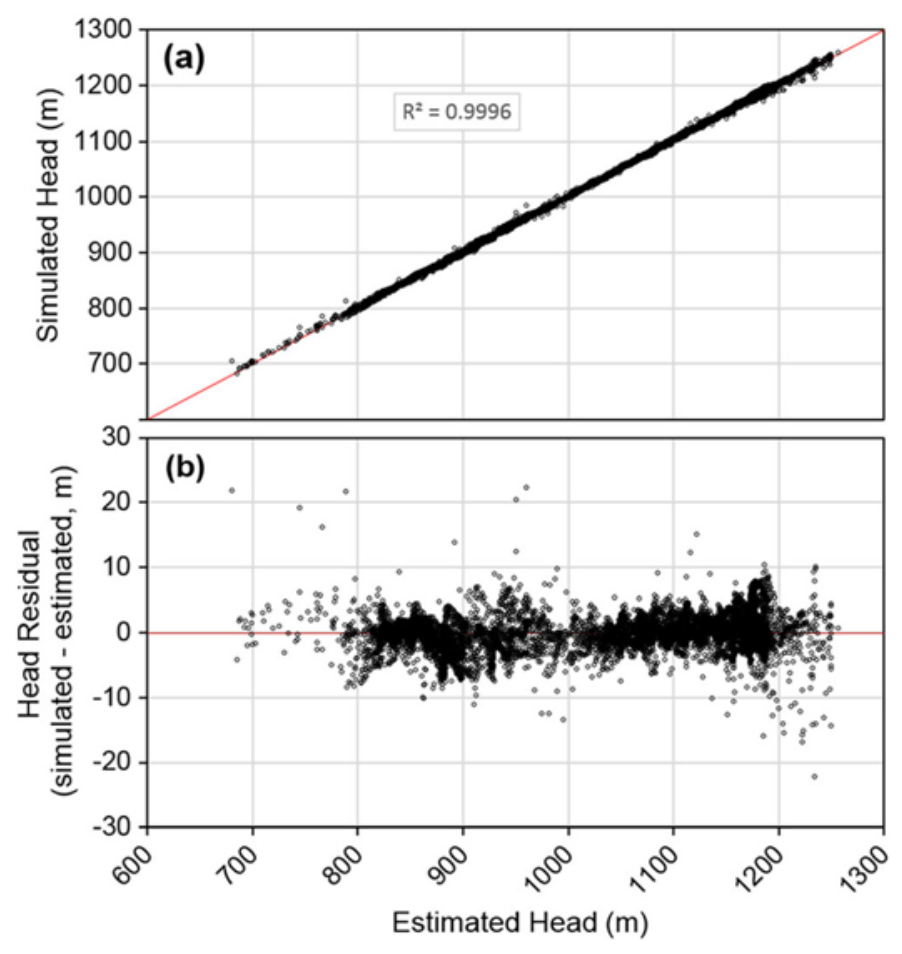

Fig. 7. Comparison of simulated and observed (estimated) hydraulic heads at all 7,937 grid cells with head targets used during automatic calibration; a) simulated and estimated hydraulic heads (correlation coefficient, $R^{2}$, is 0.9996); and b) head residuals plotted with respect to estimated hydraulic heads.

such a small overall change supports the emphasis of assigning higher weight to the recharge data from remote sensing than to $K$. The range of values remained unchanged, having a minimum of $-588 \mathrm{~mm} / \mathrm{yr}$ and a maximum of $249 \mathrm{~mm} / \mathrm{yr}$. The spatial distribution of manual adjustments made to $\mathrm{GR}_{\mathrm{n}}$ during calibration is depicted on Fig. S4 of the Supplementary Materials.

Figure 8a,b present maps of the calibrated $K$ and transmissivity fields achieved, respectively. Much of the northern half of the study area has lower $K$ than the southern half-consistent with the spatial distribution of thicker Pliocene/Pleistocene deposits in the NSH (Bleed and Flowerday 1998). The calibrated transmissivity ranges from 0 to $4,090 \mathrm{~m}^{2} / \mathrm{d}$, and has a mean of $1,156 \mathrm{~m}^{2} / \mathrm{d}$ and a median of $1,018 \mathrm{~m}^{2} \mathrm{~d}$. Hydraulic conductivity within the study area ranges from 1.6 to $30.2 \mathrm{~m} / \mathrm{d}$, and has a mean of $7.8 \mathrm{~m} / \mathrm{d}$. The mean calibrated $K$ at each of the 261 borehole locations is $8.5 \mathrm{~m} / \mathrm{d}$, about $3 \mathrm{~m} / \mathrm{d}$ lower than the mean of published estimates from borehole lithology $(11.5 \mathrm{~m} / \mathrm{d})$. Approximately $83 \%$ of the 


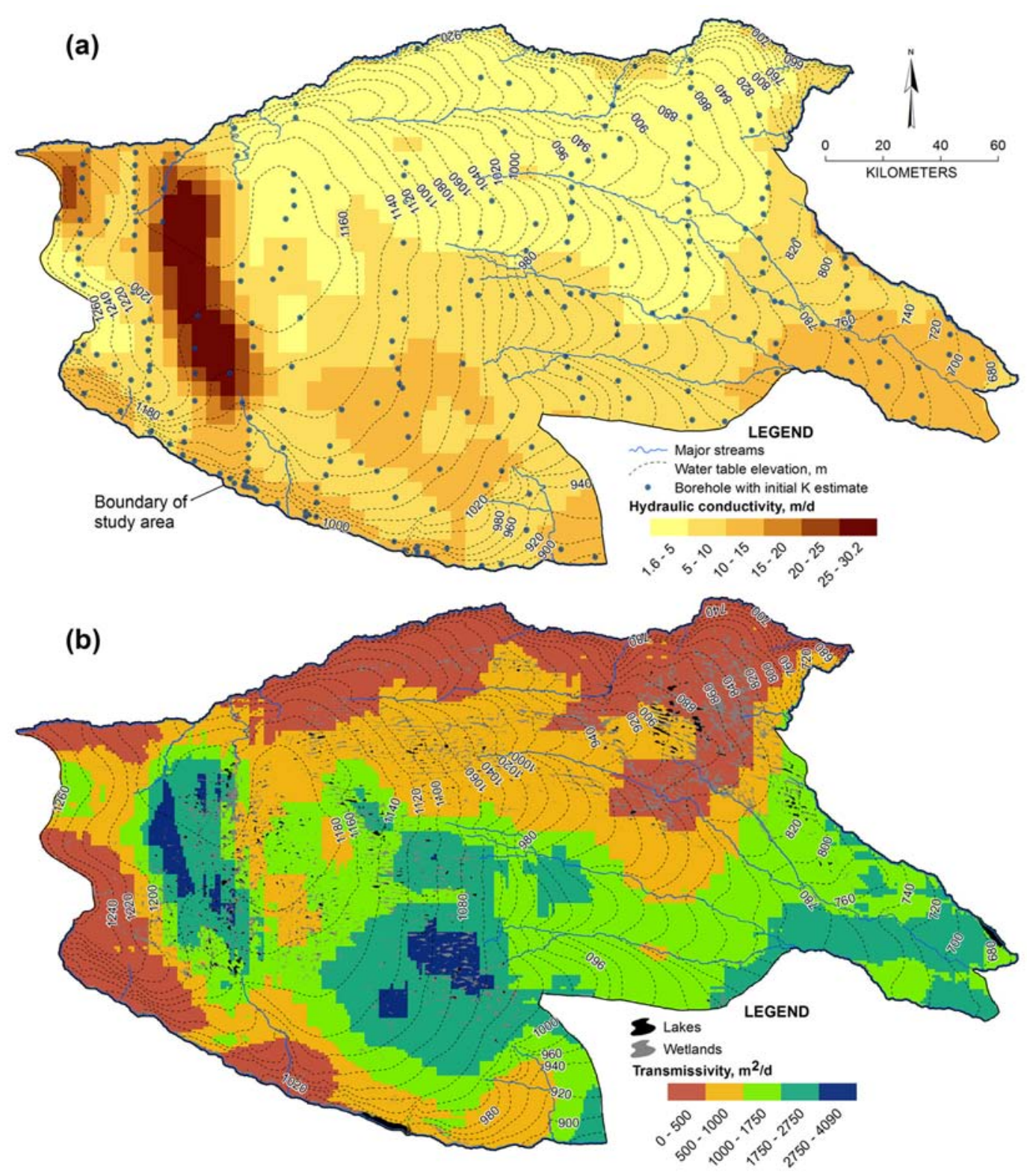

Fig. 8. Calibrated hydraulic conductivity and transmissivity distribution: a) hydraulic conductivity in $\mathrm{m} / \mathrm{d}$; and $\mathbf{b}$ ) transmissivity in $\mathrm{m}^{2} / \mathrm{d}$. Water-table elevation contours, borehole locations, lakes, wetlands and major streams are shown for reference.

differences between borehole and calibrated $K$ values are within \pm 10 $\mathrm{m} / \mathrm{d}$. Further, the calibrated $K$ values are close to those reported by Chen and Chen (2004), and have a spatial distribution that is generally similar to published interpolations based on borehole lithology (Korus et al. 2013). Considering the nonuniform distribution of boreholes over the 
study area and the low density (one borehole per $152 \mathrm{~km}^{2}$ ), these differences are reasonable at the regional scale. In addition, the calibrated values of $K$ were similar to those from previous studies in the region (see Table S3 of the Supplementary Materials).

\section{Simulated water budget}

The volumetric water budget estimates (Table 1) include simulated net groundwater discharge to internal streams. During the recent period, representing approximately 1995-2009 average conditions, total flows to and from the High Plains aquifer in the study area were simulated to be $7.75 \times 10^{6} \mathrm{~m}^{3} / \mathrm{d}$. Inflows to the aquifer were dominated by $\mathrm{GR}_{\mathrm{n}}$ to the water table (80.5\% of inflows), followed by underflows from outside the model domain through constant heads located primarily along the western border (15.4\%), and stream leakage from rivers (4.1\%). Outflows from the aquifer were dominated by flows to streams through drain and river cells (58.6\% of outflows), followed by underflow to areas outside the model domain (along the eastern and northeastern boundaries) through constant heads (34.0\%) and internal cells with net dischargenegative $\mathrm{GR}_{\mathrm{n}}(7.4 \%$ of outflows).

The calibrated model parameters were used for evaluation of simulated baseflow, calculated as total discharge via drain cells and total net discharge via river cells. The resulting calibrated groundwater discharge to streams is $4.22 \times 10^{6} \mathrm{~m}^{3} / \mathrm{d}$. This value is remarkably close $(0.8 \%$ greater $)$ to the estimate of $4.185 \times 10^{6} \mathrm{~m}^{3} / \mathrm{d}$ for observation-based baseflow obtained from independent USGS streamflow gauge data, auxiliary evidence that the hydrogeologic system has been adequately represented.

Table 1 Volumetric water budget for the entire study area

\begin{tabular}{|c|c|c|c|c|c|}
\hline \multirow{2}{*}{$\begin{array}{l}\text { Water budget component/ } \\
\text { boundary condition type }\end{array}$} & \multicolumn{2}{|l|}{ Inflow } & \multicolumn{2}{|l|}{ Outflow } & \multirow{2}{*}{$\begin{array}{l}\text { Inflow-Outflow } \\
10^{6} \mathrm{~m}^{3} / \mathrm{d}\end{array}$} \\
\hline & $10^{6} \mathrm{~m}^{3} / \mathrm{d}$ & Percent & $10^{6} \mathrm{~m}^{3} / \mathrm{d}$ & Percent & \\
\hline Recharge/discharge $\left(\mathrm{GR}_{\mathrm{n}}\right)$ & 6.24 & 80.5 & 0.57 & 7.4 & 5.67 \\
\hline Constant heads & 1.20 & 15.4 & 2.64 & 34.0 & -1.44 \\
\hline Rivers & 0.32 & 4.1 & 1.08 & 13.9 & -0.76 \\
\hline Drains & 0 & 0 & 3.46 & 44.7 & -3.46 \\
\hline Total & 7.75 & 100 & 7.75 & 100 & 0 \\
\hline
\end{tabular}


From the 1,900 grid cells containing natural lakes and wetlands larger than 10 ha (out of the 7,937 selected head target grid cells), a total of $0.18 \times 10^{6} \mathrm{~m}^{3} / \mathrm{d}$ of water discharges from the model ( $2.3 \%$ of outflows), based on the remote sensing-based estimates $(\mathrm{ET}>P)$. This represents only about $32 \%$ of all the net discharge via ET from the land surface where ET exceeds $P$, including natural lakes and wetlands (in uplands and in river valleys), engineered reservoirs, groundwater irrigated areas (especially Box Butte County), and afforested areas.

\section{Lake and wetland characteristics inferred from models of the wa- ter table}

The spatial distribution of lakes and wetlands inferred from the simulated hydraulic heads and the GIS mapping analysis (section "Lakes and wetlands") are shown on Fig. 9, and have an area of 2,083 $\mathrm{km}^{2}$, equaling $6.48 \%$ of the $32,122-\mathrm{km}^{2}$ portion of the study area assessed for lakewetland characteristics. The ability of a data set to match the observed

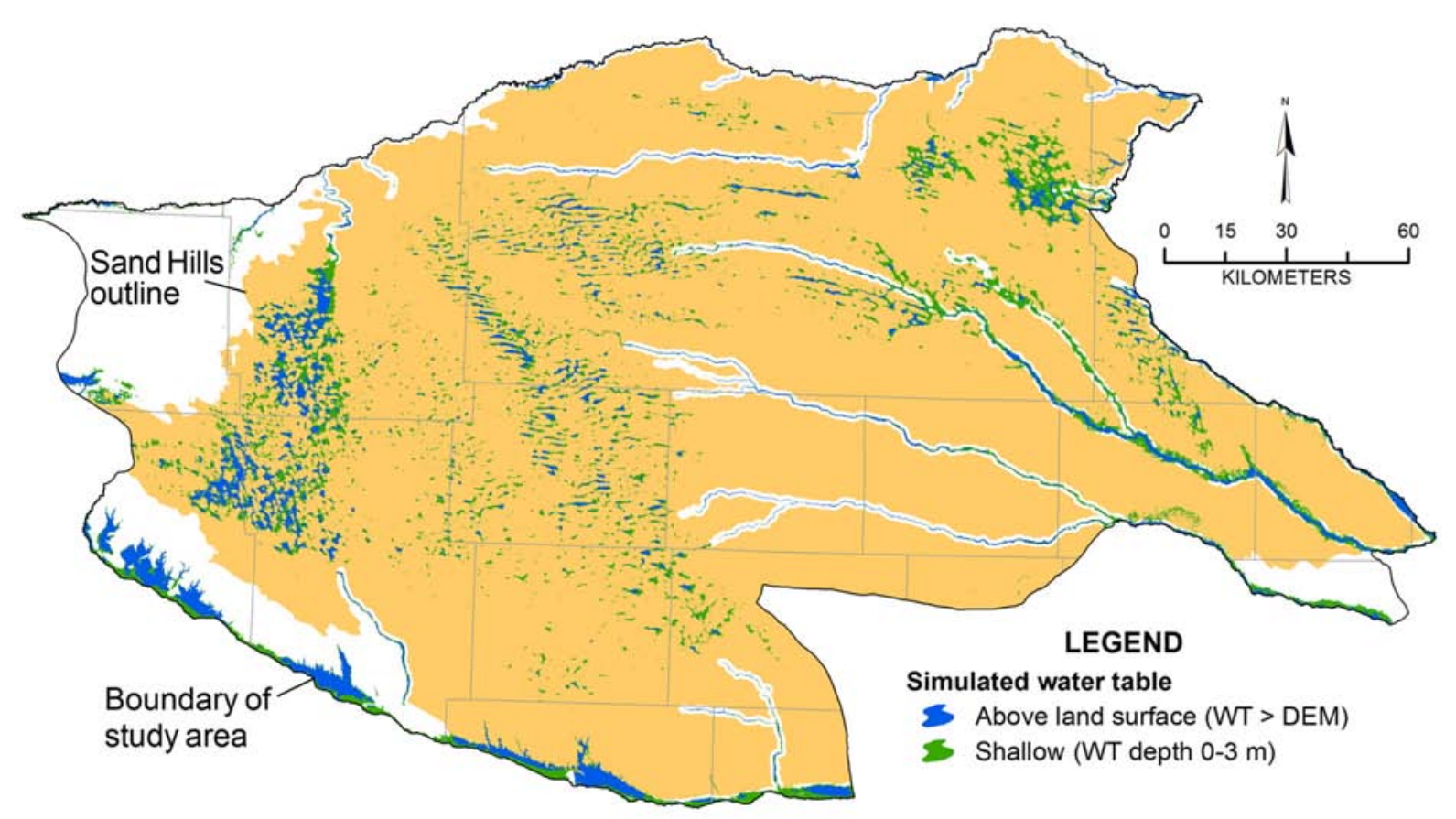

Fig. 9. Simulated spatial distribution of lakes and wetlands in the study area and Sand Hills region based on the calibrated hydraulic heads and water table (WT) depth classification. 
position in the landscape of numerous closely spaced, but widely distributed lakes and wetlands is an indication of the model fidelity.

Further quantitative evaluation of the calibration included a comparison between areas and numbers of lakes and wetlands from the three data sets depicted in Fig. 5, as well as the area of lakes from the 19791980 Landsat survey detailed by Rundquist (1983), and the NHD highresolution data set, surveyed between October 2004 and April 2008 (Table 2). Simulation of combined lake-wetland areas from hydraulic heads are remarkably similar to the estimates inferred from the 1995 regional water-table map (1.0\% underestimate), but are much less similar to those from the 2005 Landsat land cover survey (10.9\% overestimate). Similarly, the numbers of lakes, and lakes or wetlands, from the simulated hydraulic heads are remarkably similar to those from the 1995

Table 2 Total areas $\left(\mathrm{km}^{2}\right)$ and numbers of lakes and wetlands obtained using simulation results and observational data sets. ${ }^{\mathrm{a}, \mathrm{b}, \mathrm{c}}$

\begin{tabular}{|c|c|c|c|c|c|}
\hline \multirow[b]{2}{*}{ Data set } & \multicolumn{4}{|c|}{$\begin{array}{c}\text { Areas }\left[\mathrm{km}^{2}\right] \\
\text { (\% of total area assessed) }\end{array}$} & \multirow{2}{*}{$\begin{array}{l}\text { No. of lakes } \\
\text { (No. of lakes } \\
\text { or wetlands) }\end{array}$} \\
\hline & $\begin{array}{l}\text { Lakes and wetlands } \\
\text { combined }\end{array}$ & Wetlands & Lakes & Other & \\
\hline Simulated hydraulic heads & $\begin{array}{l}2,083 \\
(6.48)\end{array}$ & $\begin{array}{l}1,364 \\
(4.25)\end{array}$ & $\begin{array}{c}719 \\
(2.24)\end{array}$ & $\begin{array}{l}30,038 \\
(93.51)\end{array}$ & $\begin{array}{c}3,348 \\
(7,331)\end{array}$ \\
\hline 1995 regional water-table & $\begin{array}{l}2,104 \\
(6.55)\end{array}$ & $\begin{array}{l}1,551 \\
(4.83)\end{array}$ & $\begin{array}{c}553 \\
(1.72)\end{array}$ & $\begin{array}{l}30,018 \\
(93.45)\end{array}$ & $\begin{array}{c}3,685 \\
(8,777)\end{array}$ \\
\hline $\begin{array}{l}1995 \text { regional water-table } \\
\text { (DEM-adjusted) }\end{array}$ & $\begin{array}{l}2,147 \\
(6.68)\end{array}$ & $\begin{array}{l}2,147 \\
(6.68)\end{array}$ & $\begin{array}{c}0 \\
(0)\end{array}$ & $\begin{array}{l}29,975 \\
(93.32)\end{array}$ & $\begin{array}{c}0 \\
(8792)\end{array}$ \\
\hline $\begin{array}{l}2005 \text { Landsat survey } \\
\quad \text { (Dappen et al. 2007) }\end{array}$ & $\begin{array}{l}1,879 \\
(5.85)\end{array}$ & $\begin{array}{l}1,625 \\
(5.06)\end{array}$ & $\begin{array}{c}254 \\
(0.79)\end{array}$ & $\begin{array}{l}30,242 \\
(94.15)\end{array}$ & $\begin{array}{c}4,699 \\
(44,213)\end{array}$ \\
\hline $\begin{array}{l}\text { 1979-1980 Landsat survey } \\
\text { (Rundquist 1983) }\end{array}$ & y & - & $\begin{array}{c}331 \\
(1.03)\end{array}$ & - & - \\
\hline $\begin{array}{l}\text { 2004-2008 National } \\
\text { Hydrography Dataset }\end{array}$ & - & - & $\begin{array}{c}302 \\
(0.94)\end{array}$ & - & - \\
\hline
\end{tabular}

a. Area included for assessment of lake and wetland areas, and numbers, includes only the NSH portion of the study area and excludes major river valleys; it amounts to an area of $32,122 \mathrm{~km}^{2}$ b. DEM-adjustment of the 1995 regional water-table map led to there not being any mapped water-table elevations greater than the land surface, resulting in there being no lakes in the GIS classification

c. Areas of lakes from the 1979-1980 Landsat survey presented in Rundquist (1983), and the NHD, were multiplied by 0.728 - the fraction of (1) the area of lakes over the portion of the study area assessed $\left(32,122 \mathrm{~km}^{2}\right)$ to (2) area of lakes in the entire NSH proper (see Figs. 1 and 2) as surveyed in the 2005 Landsat survey $\left(0.728=254 \mathrm{~km}^{2} \div 349 \mathrm{~km}^{2}\right)$ 
regional water table map $(9.1 \%$ underestimate for lake numbers, and $16.5 \%$ underestimate for lake or wetland numbers), but are less similar than the 2005 Landsat survey (21.6\% underestimate for lake numbers, and $83.4 \%$ underestimate for lake or wetland numbers). Additionally, the resulting areas of lakes from the simulated heads and the regional water-table map are much larger than areas obtained from the other two surveys (Table 2). Further assessment of the areas of mismatch between simulated and observed (2005 Landsat survey) locations and areas of lakes and wetlands are presented in Table S4 and Fig. S5 of the Supplementary Materials, along with a short discussion of ways in which the mismatch could be improved.

\section{Discussion}

Discrepancies between the simulated and observed lake areas and wetland areas, separately, are noteworthy, as well as those between simulated and observed numbers of lakes, and lakes or wetlands. However, the resulting mismatch among the combined lake-wetland areas is much smaller. This is a reasonable result for the approach and important when considering the degree of variability between areas of lakes from the three observational data sets (2005 and 1979-1980 Landsat surveys, and NHD): the coefficient of variation is $13 \%$, with an even larger range, compared with a simulated $11 \%$ overestimate of combined lake-wetland areas. The results are encouraging, despite recognizing the drawbacks, and suggest room for future improvements that could be implemented (Section S4 of the Supplementary Materials).

The mismatch for individual lake and wetland areas and numbers is largely attributed to deficiencies in the calibration data set (hydraulic heads supplemented with DEM elevations), as well as the fact that the topographic variation (dune landscape) does not necessarily match that of the available data (regional); here, the regional (15.24-m interval) contour map to generate head targets for 1-km resolution MODFLOW grid cells was used. In addition, interpolation of the simulated heads down to a resolution of the DEM(30 $\mathrm{m})$ was performed before conducting the GIS terrain analysis to infer the position of lakes and wetlands. Another factor affects the model performance- selection of a 3-m water-table depth used to classify wetlands from lakes. This value was obtained by comparing to other depth cutoffs. Finally, classification of shallow lakes 
has inherent difficulties due to seasonal transitions into wetlands; and accuracy of observations of model inputs, water level targets, DEM, and Landsat survey data has not been fully quantified, thereby making it difficult to identify and reduce uncertainties related to calibration and simulation of lake-wetland characteristics.

In this example, the calibration data set only included hydraulic head estimates, yet the results provide a very good match to baseflow data $(+0.8 \%)$ that were obtained independently. In some cases, there are physical reasons for errors in the simulation of lake-wetland characteristics - for example, aquifer heads can be above the land surface near springs, as have been observed in the field in southwestern parts of the NSH (Befus et al. 2012). Importantly, the discrepancies of simulated and observed total lake and wetland areas do not preclude the use of the model for predicting the overall system dynamics at regional groundwater management scales due to changing stresses.

The principle of parsimony was applied during model construction: relatively coarse grid spacing, honoring available $\mathrm{GR}_{\mathrm{n}}$, and using one model layer without explicit consideration of groundwater exchange with lakes or wetlands. Such an approach avoided 3-D discretization that demands extensive, and rarely available, high-resolution data sets of vertical variations of aquifer and lakebed layering/geometry and properties, and inclusion of vadose zone dynamics. Such detailed data on the scale of this study area $\left(\sim 40,000 \mathrm{~km}^{2}\right)$ are largely unavailable today in the NSH and elsewhere in the world. Study of the large area with heterogeneity and topographic variation was facilitated by the automatic calibration technique, granted the problem was reduced in complexity by constraining the inverse problem with long-term estimates of $\mathrm{GR}_{\mathrm{n}}$ from remote sensing (MODIS-based; Szilagyi and Jozsa 2013). Another approach representing individual lakes through the use of high- $K$ cells (Anderson et al. 2015) is not appropriate in this case, because most lakes in the NSH are very shallow-less than $\sim 1 \mathrm{~m}$ on average (McCarraher 1977), and many of the lakebeds have lower $K$ than the surrounding aquifer (Ahlbrandt and Fryberger 1980; Ong and Zlotnik 2011). Application of the approach to other areas would require similar $\mathrm{GR}_{\mathrm{n}}$ estimates, which inherently include net evaporation $(E)$ from lakes $(E-P)$. Since the lakes were shallow, no correction of DEM elevations was required (subtracting lake depth from the DEM), but in places with deeper lakes, bathymetry should be obtained to complete the GIS terrain analysis. 
Accuracy of the existing water-table map is a leading factor controlling accuracy of the proposed approach. This hand-drawn map utilized primary information (water levels) sampled by 339 measurement points (i.e. less than one well per $100 \mathrm{~km}^{2}$ ) and secondary information (land surface topography, hydrographic stream network, and shallow lake elevations). Higher weights were applied to head targets during calibration in areas of both primary and secondary information. Data indicate excellent stability of water levels over the development period (over 50 years!; McGuire 2014). This map has a long and successful history of use in Nebraska state water resources projects. Various studies explored the role of mapping techniques recently (e.g. Fasbender et al. 2008; Woodrow et al. 2016). Typically, they require much higher density of sampling points (about one per $10 \mathrm{~km}^{2}$ ) and remain in the research stage. (The current water-table map also undergoes revisions by the UNL-CSD with aid of GIS and geostatistics).

The groundwater model simulates the interpreted regional water-table position and overall baseflow after applying a combination of manual adjustment of $\mathrm{GR}_{\mathrm{n}}$ and automatic adjustment of $K$. Improved fit with observational land cover data sets might be achieved by utilizing the spatial information as part of the regularization in PEST (see other suggestions in section S4 of the Supplementary Materials). The use of spatially distributed $\mathrm{GR}_{\mathrm{n}}$ has been carried out previously in groundwater model calibration (e.g. Hendricks Franssen et al. 2008; Li et al. 2009). The manual adjustments of $\mathrm{GR}_{\mathrm{n}}$ performed in this study had subjective elements (127 zones) and the resulting rates from the calibration are not guaranteed to provide the best model fit (i.e. non-unique). Realistically, the level of uncertainty inherent in the $K$ parameter, and the correlation between $\mathrm{GR}_{\mathrm{n}}$ and $K$, would not have made a meaningful difference if $\mathrm{GR}_{\mathrm{n}}$ had been adjusted simultaneously with PEST (Knowling and Werner 2016). On the contrary, simultaneous adjustments may have caused numerical longer computation time and numerical convergence issues. Instead, the externally calculated $\mathrm{GR}_{\mathrm{n}}$ rates, constrained by remote sensing data, were emphasized. Resulting manual adjustments were lower than the expected error for the NSH. The relatively small changes to $\mathrm{GR}_{n}$ indicate the high level of reliability of the original $\mathrm{GR}_{\mathrm{n}}$ estimates of Szilagyi and Jozsa (2013).

An unexpected result from this work, relating to the final $K$ map, deserves some discussion-despite a good model calibration at the large area with a shallow water-table and at the water-table saddle in the 
west-central part of the domain (defined by tracing the 1,180 m contour shown on Figs. 3 and 6), the area has not previously been reported to harbor anomalously high $K$ (see Fig. 8a). The water-table gradient is relatively small ( $\sim 0.0005-0.001)$ around this saddle, and the manual calibration to heads in this area (step 1) was unsatisfactory. Explanations for the existence of the high- $K$ area are presented as follows:

1. The anomaly is real but not apparent because of sparse borehole data-only six boreholes are located in this part of the study area (Fig. 8a). There is evidence of paleovalleys filled with deposits of young, relatively high- $K$ material, deposited before being blocked by wind-blown dune dams during the Holocene (cf. Loope et al. 1995);

2. The fixed structure of the model domain underestimates aquifer thickness (related to borehole density). If the thickness of the aquifer in this area were larger, $K$ values would need to be decreased, potentially removing the anomaly.

3. Groundwater discharge is underestimated (i.e. ET is too lowwhich has been suggested of the MODIS-based ET estimation method for open water by about 10\% (Szilagyi et al. 2011b). However, the ET was effectively increased over initial estimates during calibration in this area by a similar magnitude through adjustments made to $\mathrm{GR}_{\mathrm{n}}$ (shown on Fig. S4 of the Supplementary Materials).

Since these factors could all contribute to the high- $K$ anomaly obtained, this issue persists, and the possible explanations provided here should be considered as hypotheses for future hydrogeologic study. The proposed approach requires a regional water-table map, remote sensing estimates of $\mathrm{GR}_{\mathrm{n}}$, basic data on aquifer hydrogeology, and a DEM of land surface elevation. Such information is often available in semiarid regions where there is interest in the fate of extensive shallow groundwater lake systems, and associated biodiversity. Examples can be found in Kazakhstan (Saryarka World Heritage site; UNESCO 2017), Inner Mongolia (e.g. Ordos Desert; Tao et al. 2015), and Australia (Western Australia; Turner and Townley 2006). Naturally, in regions with less permeable substrate (Prairie Pothole Region, Canada) and regions where playas exist perched far above the water table (Central and Southern High Plains aquifer), with little connection between groundwater and surface water, this approach will be invalid (Liu and Schwartz 2011, 2014). 


\section{Conclusions}

The presented approach, designed for process-based modeling of hydrogeologic systems with thousands of shallow groundwater-fed lakes and wetlands, was applied in the Nebraska Sand Hills (NSH). The approach addresses the need to simulate future changes to large lake and wetland environments, as recent climate change and human demands have stressed existing water resources. Typically, systems with just a few lakes have been simulated, with the focus on local groundwater/surface-water exchange rates and water budgets of individual lakes. Simulating thousands of lakes and wetlands at the regional groundwater management scale is typically thwarted by data availability, regional heterogeneity, and process complexity. Therefore, traditional numerical groundwater modeling and GIS terrain analysis techniques were utilized, along with the idea that, in moderately to highly permeable soils and strata, groundwater discharge is focused in depressions where the regional potentiometric surface is high. The variable topography and hydraulic connection between the interdunal depressions and their lakes and wetlands with the underlying saturated units of the High Plains aquifer make it an ideal setting for evaluating the feasibility of the approach.

In the process of constructing a groundwater model, a better understanding of the NSH system properties and functioning has been attained. The long-term average hydrology of the NSH lake-aquifer system is controlled by net groundwater recharge $\left(\mathrm{GR}_{\mathrm{n}}\right)$, the land surface topography, aquifer transmissivity, and the drainage network of regional and headwater streams. After completing the groundwater modeling, auxiliary evaluation of the model results was made by comparing the overall water budget with total baseflow to interior streams and the spatial distribution, and areas and numbers of lakes and wetlands. With this approach, major system traits are captured at the regional groundwater management scale unlike in modeling studies of single lakes.

The principle of parsimony was applied. The approach presented here strives to use the simplest possible model, with the utmost reliance on available data. The application focuses on the interpreted (and interpolated) water-table distribution, comparing regional water-table elevations with land surface elevations from a DEM, completed by inference of locations of thousands of lakes and wetlands with a specified water-table depth classification criteria. With use of GIS, the approach 
reveals areas covered by lakes and wetlands, and when combined with image analysis software (MATLAB cluster analysis script in this case), also their numbers. With respect to model parameterization and calibration, this study uses a practical example to suggest that methods that start with simple models and use computationally frugal model analysis methods remain valuable in model development methods (cf. La Vigna et al. 2016). In this case, a relatively coarse grid spacing was used, just one model layer, and no explicit coupling between small lakes or wetlands (average depth of $\sim 1 \mathrm{~m})$ and the large $\left(\sim 40,000 \mathrm{~km}^{2}\right)$ groundwater system. The approach lays the background for research of climate and land-use changes on regional lake and wetland characteristics, in both the NSH and elsewhere. This is because the observed bias in total lake and wetland areas and numbers does not preclude the use of the model as a tool to evaluate consequences to ecologically important streamflow, and groundwater-fed lakes and wetlands, resulting from global and regional climate change and other human-induced environmental stresses.

Acknowledgments - This research was partially supported by a grant from the National Science Foundation IGERT program (DGE-0903469) and the Daugherty Water for Food Institute, University of Nebraska-Lincoln. Staff of the CSD (UNL), CALMIT (UNL), and the USGS made available crucial data sources for the construction and calibration of the groundwater flow model. J. Szilagyi (CSD) provided the net groundwater recharge data set. T. Franz (UNL) provided the MATLAB script used to calculate lake and wetland numbers, and L. Howard (UNL) provided assistance with ArcGIS analyses. A. Brookfield (KGS, Univ. Kansas) consulted on the HydroGeoSphere software during early stages of this work. We also acknowledge staff of Waterloo Hydrogeologic (formerly Schlumberger Water Services) for providing technical guidance in the use of Visual MODFLOW Flex software.

\section{References}

Ahlbrandt TS, Fryberger SG (1980) Eolian deposits in the Nebraska Sand Hills. US Geol Surv Prof Pap 1120A. pp 1-24

Ala-aho P, Rossi PM, Isokangas E, Klove B (2015) Fully integrated surface-subsurface flow modelling of groundwater-lake interaction in an esker aquifer: model verification with stable isotopes and airborne thermal imaging. J Hydrol 522:391406. https://doi.org/10.1016/i.jhydrol.2014.12.054

Anderson MP, Woessner WW, Hunt RJ (2015) Applied groundwater modeling: simulation of flow and advective transport, 2nd edn. Academic, San Diego, CA 
Ayers JF (2007) Box Butte County-Niobrara River numerical groundwater flow model. Project completion report. Available at https://dnrnebraskagov/sites/ dnrnebraskagov/files/doc/water-planning/niobrara/publications/Box-Butte_ ModelProjectCompletionReportpdf Accessed 25 October 2017

Befus KM, Cardenas MB, Ong JB, Zlotnik VA (2012) Classification and delineation of groundwater-lake interactions in the Nebraska Sand Hills (USA) using electrical resistivity patterns. Hydrogeol J 20(8): 1483-1495. https://doi.org/10.1007/ $\underline{\text { s10040-012-0891-X }}$

Beven K (2012) Rainfall-runoff modelling: the primer. Wiley, Chichester, UK

Bleed AS, Flowerday CA (1998) An atlas of the Sand Hills, 3rd edn. Conservation and Survey Division, University of Nebraska-Lincoln, Lincoln, NE, 260 pp

Brunner P, Doherty J, Simmons CT (2012) Uncertainty assessment and implications for data acquisition in support of integrated hydrologic models. Water Resour Res 48:W07513. https://doi.org/10.1029/2011WR011342

Carney CP (2008) Groundwater flow model of the Central Model Unit of the Nebraska Cooperative Hydrology Study (COHYST) area. COHYST technical report, COHYST, Lincoln, NE. Available at http://cohystnebraskagov/adobe/dc012CMU GFMR 081224pdf Accessed 25 October 2017

Chen X, Chen X (2004) Simulating the effects of reduced precipitation on ground water and streamflow in the Nebraska Sand Hills. J Am Water Resour Assoc 40(2):419-430. https://doi.org/10.1111/j.1752-1688.2004.tb01040.x

Chen X, Chen X, Rowe C, Hu Q, Anderson M (2003) Geological and climatic controls on streamflows in the Nebraska Sand Hills. J Am Water Resour Assoc 39(1):217228. https://doi.org/10.1111/j.1752-1688.2003.tb01573.x

Dappen P, Merchant J, Ratcliffe I, Robbins C (2007) Delineation of 2005 land use patterns for the state of Nebraska Department of Natural Resources. Final report, Center for Advanced Land Management Information Technologies. University of Nebraska-Lincoln, Lincoln, NE. Available at https://calmit.unl.edu/pdf/2005 Landuse FinalReport.pdf Accessed 25 October 2017

Doherty JE, Fienen MN, Hunt RJ (2010) Approaches to highly parameterized inversion: pilot-point theory, guidelines, and research directions. US Geol Surv Sci Invest Rep 2010-5168. 36 pp

Donovan JJ, Smith AJ, Panek VA, Engstrom DR, Ito E (2002) Climate-driven hydrologic transients in lake sediment records: calibration of groundwater conditions using 20th century drought. Quat Sci Rev 21:605-624

Fasbender D, Peeters L, Bogaert P, Dassargues A (2008) Bayesian data fusion applied to water table spatial mapping. Water Resour Res 44: W12422. https://doi. org/10.1029/2008WR006921

Feinstein DT, Dunning CP, Juckem PF, Hunt RJ (2010a) Application of the Local Grid Refinement package to an inset model simulating the interactions of lakes, wells, and shallow groundwater, northwestern Waukesha County, Wisconsin. US Geol Surv Sci Invest Rep 2010- 5214. 30 pp

Feinstein DT, Hunt RJ, Reeves HW (2010b) Regional groundwater-flow model of the Lake Michigan Basin in support of Great Lakes Basin water availability and use studies. US Geol Surv Sci Invest Rep 2010-5109. 379 pp 
Ginsberg MH (1987)Water-budget model of the south-central Sand Hills of Nebraska. PhD Thesis, University of Nebraska-Lincoln, Lincoln, NE. Available at http://digitalcommons.unl.edu/dissertations/AAI8717252/ Accessed 2 March 2013

Gosselin DC, Rundquist DC, McFeeters SK (2000) Remote monitoring of selected ground-water dominated lakes in the Nebraska Sand

Hills. J Am Water Resour Assoc 36(5):1039-1051. https://doi. org/10.1111/j.1752-1688.2000.tb05708.x

Harvey FE, Swinehart JB, Kurtz TM (2007) Ground water sustenance of Nebraska's unique Sand Hills peatland fen ecosystems. Groundwater 45(2):218-234. https:// doi.org/10.1111/j.1745-6584.2006.00278.x

Healy RW (2010) Estimating groundwater recharge. Cambridge University Press, Cambridge, UK

Haitjema HM, Mitchell-Bruker S (2005) Are water tables a subdued replica of the topography? Groundwater 43(6):781-786. https://doi. org/10.1111/j.1745-6584.2005.00090.x

Hendricks Franssen HJ, Brunner P, Makobo P, Kinzelbach W (2008) Equally likely inverse solutions to a groundwater flow problem including pattern information from remote sensing images. Water Resour Res 44:W01419. https://doi. org/10.1029/2007WR006097

Hunt RJ, Haitjema HM, Krohelski JT, Feinstein DT (2003) Simulating ground waterlake interactions: approaches and insights. Groundwater 41(2):227-237. https:// doi.org/10.1111/j.1745-6584.2003.tb02586.x

Junk WJ, An S, Finlayson CM, Gopal B, Kvet J, Mitchell SA, Mitsch WJ, Robarts RD (2013) Current state of knowledge regarding the world's wetlands and their future under global climate change: a synthesis. Aquat Sci 75:151-167. https:// doi.org/10.1007/s00027-012-0278-Z

Klove B, Ala-aho P, Bertrand G, Gurdak JJ, Kupfersberger H, Kvaerner J, Muotka T, Mykra H, Preda E, Rossi P, Uvo CB, Velasco E, Pulido-Velazquez M (2014) Climate change impacts on groundwater and dependent ecosystems. J Hydrol 518:250266. https://doi.org/10.1016/i.jhydrol.2013.06.037

Knowling MJ, Werner AD (2016) Estimability of recharge through groundwater model calibration: insights from a field-scale steady-state example. J Hydrol:973-987. https://doi.org/10.1016/i.jhydrol.2016.07.003

Korus JT, Burbach ME, Howard LM, Joeckel RM (2011) Nebraska statewide groundwater-level monitoring report 2010. Nebraska Water Surv Pap 77, Conservation and Survey Division, University of Nebraska-Lincoln, Lincoln, NE, 19 $\mathrm{pp}$

Korus JT, Howard LM, Young AR, Divine DP, Burbach ME, Jess JM, Hallum DR (2013) The groundwater atlas of Nebraska. Resource Atlas no. 4b/2013, 3rd edn. Conservation and Survey Division, University of Nebraska, Lincoln, NE, 64 pp

La Vigna F, Hill MC, Rossetto R, Mazza R (2016) Parameterization, sensitivity analysis, and inversion: an investigation using groundwater modeling of the surface-mined Tivoli-Guidonia basin (Metropolitan City of Rome, Italy). Hydrogeol J 24(6):1423-1441. https://doi.org/10.1007/s10040-016-1393-z 
Lemieux J-M, Sudicky EA, Peltier WR, Tarasov L (2008) Dynamics of groundwater recharge and seepage over the Canadian landscape during the Wisconsinian glaciation. J Geophys Res 113(F01011). https://doi.org/10.1029/2007JF000838

Li HT, Brunner P, Kinzelbach W, Li WP, Dong XG (2009) Calibration of a groundwater model using pattern information from remote sensing data. J Hydrol 377(12):120-130. https://doi.org/10.1016/i.jhydrol.2009.08.012

Liu G, Schwartz FW (2011) An integrated observational and model-based analysis of the hydrologic response of prairie pothole systems to variability in climate. Water Resour Res 47:W02504. https://doi.org/10.1029/2010WR009084

Liu G, Schwartz FW (2014) On modeling the paleohydrologic response of close-basin lakes to fluctuations in climate: methods, applications, and implications. Water Resour Res 50:2975-2992. https://doi.org/10.1002/2013WR014107

Liu H, Yin Y, Piao S, Zhao F, Engels M, Ciais P (2013) Disappearing lakes in semiarid northern China: drivers and environmental impact. Environ Sci Technol 47(21):12107-12114. https://doi.org/10.1021/es305298q

Loope DB, Swinehart JB, Mason JP (1995) Dune-dammed paleovalleys of the Nebraska Sand Hills: intrinsic versus climatic controls on the accumulation of lake and marsh sediments. Geol Soc Am Bull 107(4):396-406

Luckey RR, Cannia JC (2006) Groundwater flow model of the Western Model Unit of the Nebraska Cooperative Hydrology Study (COHYST) area. COHYST technical report, COHYST, Lincoln, NE. Available at ftp://ftpdnrnebraskagov/Pub/ cohystftp/cohyst/model reports/WMU Documentation 060519pdf Accessed 25 October 2017

Luckey RR, Gutentag ED, Heimes FJ, Weeks JB (1986) Digital simulation of groundwater flow in the High Plains aquifer in parts of Colorado, Kansas, Nebraska, New Mexico, Oklahoma, South Dakota, Texas, and Wyoming. US Geol Surv Prof Pap 1400-D. $57 \mathrm{pp}$

McCarraher DB (1977) Nebraska's Sandhills Lakes. Nebraska Game and Parks Commission, Lincoln, NE, 67 pp

McGuire VL (2014) Water-level changes and change in water in storage in the High Plains Aquifer, predevelopment to 2013 and 2011-13. US Geol Surv Sci Invest Rep 2014-5218, 14 pp

McLean JS, Chen HH, Goeke JW (1997) Simulation of ground-water flow in the High Plains Aquifer, southern Sandhills area, westcentral Nebraska. US Geol Surv Open File Rep 96-206, 16 pp

NDNR (2016) National hydrographic dataset, NDH: major streams. http:// nednrnebraskagov/Media/GISData/Annual/MajorStreamzip Accessed 25 October 2017

Ong JB (2010) Investigation of spatial and temporal processes of lake- aquifer interactions in the Nebraska Sand Hills. PhD Thesis, University of NebraskaLincoln, Lincoln, NE. Available at http://digitalcommons.unl.edu/geoscidiss/13/ Accessed 15 September 2013

Ong JB, Zlotnik VA (2011) Assessing lakebed hydraulic conductivity and seepage flux by potentiomanometer. Ground Water 49(2):270-274. https://doi. org/10.1111/j.1745-6584.2010.00717.x 
Peterson SM, Stanton JS, Saunders AT, Bradley JR (2008) Simulation of ground-water flow and effects of ground-water irrigation on base flow in the Elkhorn and Loup River basins, Nebraska. US Geol Surv Sci Invest Rep 2008-5143. 66 pp

Riordan B, Verbyla D, McGuire D (2006) Shrinking ponds in subarctic Alaska based on 1950-2002 remotely sensed images. J Geophys Res 111:G04002. https://doi. org/10.1029/2005JG000150

Rossman NR, Zlotnik VA, Rowe CM, Szilagyi J (2014) Vadose zone lag time and potential 21 st century climate change effects on spatially distributed groundwater recharge in the semi-arid Nebraska Sand Hills. J Hydrol 519:656669. https://doi.org/10.1016/j.jhydrol. 2014.07.057

Rousseau-Gueutin P, Love AJ, Vasseur G, Robinson NI, Simmons CS, de Marsily G (2013) Time to reach near-steady state in large aquifers. Water Resour Res 49:6893-6908. https://doi.org/10.1002/wrcr. 20534

Rundquist DC (1983) Wetland Inventories of Nebraska's Sandhills. Resources Rep, Publ. 9, Conservation and Survey Division, University of Nebraska-Lincoln, Lincoln, NE. Available at https://marketplace.unl.edu/nemaps/wetlandinventories-of-nebraska-ssandhills-rr-9.html Accessed 25 October 2017

Scanlon BR, Faunt CC, Longuevergne L, Reedy RC, Alley WA, McGuire VL, McMahon PB (2012) Groundwater depletion and sustainability of irrigation in the US High Plains and Central Valley. Proc Natl Acad Sci USA 109(24):9320-9325. https:// doi.org/10.1073/pnas.1200311109

Smith LC, Sheng Y, MacDonald GM, Hinzman LD (2005) Disappearing arctic lakes. Science 308(5727):1429. https://doi.org/10.1126/science.1108142

Sridhar V, Hubbard KG, Wedin DA (2006) Assessment of soil moisture dynamics of the Nebraska Sandhills using long-term measurements and a hydrology model. J Irrig Drainage Eng 132(5):463-473. https://doi.org/10.1061/ (ASCE) 0733-9437(2006)132:5(463)

Stanton JS, Peterson SM, Fienen MN (2010) Simulation of groundwater flow and effects of groundwater irrigation on stream base flow in the Elkhorn and Loup River basins, Nebraska, 1895-2055: phase two. US Geol Surv Sci Invest Rep 2010$5149.78 \mathrm{pp}$

Summerside S, Ponte M, Dreeszen VH, Hartung SL, Khisty MJ, Szilagyi J (2001) Update and revision of regional $1 \times 2$ degree water-table configuration maps for the state of Nebraska. Conservation and Survey Division, University of NebraskaLincoln, Lincoln, NE, 14 pp

Szilagyi J, Jozsa J (2013) MODIS-aided statewide net groundwater recharge estimation in Nebraska. Groundwater 51(5):735-744. https://doi. org/10.1111/j.1745-6584.2012.01019.x

Szilagyi J, Jozsa J, Kovacs A (2011b) A calibration-free evapotranspiration mapping (CREMAP) technique. In: Labedzki L (ed) Evapotranspiration. InTech, Rijeka, Croatia, pp 257-274

Szilagyi J, Zlotnik VA, Gates J, Jozsa J (2011a) Mapping mean annual groundwater recharge in the Nebraska Sand Hills, USA. Hydrogeol J 19(8):1503-1513. https:// doi.org/10.1007/s10040-011-0769-3 
Szilagyi J, Zlotnik VA, Jozsa J (2013) Net recharge versus depth to groundwater relationship in the Platte River Valley of Nebraska, United States. Groundwater 51(6):945-951. https://doi.org/10.1111/gwat.12007

Tao S, Fang J, Zhao X, Zhao S, Shen H, Hu H, Tang Z, Wang Z, Guo Q (2015) Rapid loss of lakes on the Mongolian Plateau. Proc National Acad Sci 112(7):2281-2286. https://doi.org/10.1073/pnas.1411748112

Turner JV, Townley LR (2006) Determination of groundwater flow through regimes of shallow lakes and wetlands from numerical analysis of stable isotope and chloride tracer distribution patterns. J Hydrol 320:451-483. https://doi. org/10.1016/j.jhydrol.2005.07.050

Tikhonov AN, Arsenin VY (1977) Solutions of ill-posed problems. Winston, Washington, DC

UNESCO (2017) Saryarka - Steppe and Lakes of northern Kazakhstan.

UNESCO, Paris. http://whcunescoorg/en/list/1102/ Accessed 25 October 2017

Urbano LD, Person M, Kelts K, Hanor JS (2004) Transient groundwater impacts on the development of paleoclimatic lake records in semiarid environments. Geofluids 4(3):187-196. https://doi.org/10.1111/j.1468-8123.2004.00081.x

Voss CI, Soliman SM (2014) The transboundary non-renewable Nubian Aquifer System of Chad, Egypt, Libya and Sudan: classical groundwater questions and parsimonious hydrogeologic analysis and modeling. Hydrogeol J 22(2):441-468. https://doi.org/10.1007/s1040-013-1039-3

Winter TC (1986) Effect of ground-water recharge on configuration of the water table beneath sand dunes and on seepage in lakes in the sandhills of Nebraska, USA. J Hydrol 86(3-4):221-237. https://doi. org/10.1016/0022-1694(86)90166-6

Winter TC (1990) Map distribution of the difference between precipitation and open water evaporation in North America. In: Geology of North America, Map GNA-01. USGS, Denver, CO

Woldeamlak ST, Batelaan O, De Smedt F (2007) Effects of climate change on the groundwater system in the Grote-Nete catchment, Belgium. Hydrogeol J 15(5):891-901. https://doi.org/10.1007/s10040-006-0145-x

Woodrow K, Lindsay JB, Berg AA (2016) Evaluating DEM conditioning techniques, elevation source data, and grid resolution for field-scale hydrological parameter extraction. J Hydrol 540:1022-1029. https://doi.org/10.1016/j. ¡hydrol.2016.07.018

Zlotnik VA, Olaguera F, Ong JB (2009) An approach to assessment of flow regimes of groundwater-dominated lakes in arid environments. J Hydrol 371(1-4):22-30. https://doi.org/10.1016/j.jhydrol.2009.03.012 


\title{
Supplementary Material - Hydrogeology Journal
}

\section{An approach to hydrogeological modeling of a large system of groundwater-fed lakes and wetlands in the Nebraska Sand Hills, USA}

\author{
Nathan R. Rossman*, Vitaly A. Zlotnik, and Clinton M. Rowe \\ Department of Earth and Atmospheric Sciences, \\ University of Nebraska-Lincoln, \\ 126 Bessey Hall, Lincoln, NE 68588, USA \\ ${ }^{*}$ Corresponding author current contact information: \\ HDR, Inc., 8404 Indian Hills Drive, Omaha, NE 68114, USA \\ e-mail: nrossman@huskers.unl.edu; nathan.rossman@hdrinc.com
}

This supplement provides additional information on the Nebraska Sand Hills groundwater modeling application and analysis reported in the main article. Information provided here follows the order presented in the main article, and includes: 1) Descriptions of data used in construction, calibration, and assessment of the performance of the groundwater model; 2) Description and table (Table S1) of the analysis methods used to determine estimates of stream baseflows; 3) Flowchart of processing steps taken to obtain areas and numbers of lakes and wetlands (Fig. S1); 4) Further details, and key steps (Table S2), of the model calibration; 5) Initial hydraulic conductivity zones with average values (Fig. S2); 6) Figures applying to the calibration process, including pilot points and model cells containing head targets (Fig. S3), and adjustments made to the initial estimates of groundwater recharge rates (Fig. S4); 7) Compilation of hydraulic conductivity values from previous groundwater modeling studies covering parts of the NSH (Table S3); and 8) Evaluation of areas of mismatch between simulated and remotely sensed lake and wetland locations (Table S4 and Fig. S5).

\section{S1. Description of data}

Previously published digital hydrogeologic, hydrologic, topographic, and geographic data sets were used to aid with construction, calibration, and assessing the performance of the NSH groundwater flow model described in this paper. Detailed description of these data sets and their sources are provided in the following listing:

\begin{tabular}{|c|c|}
\hline Data Set & Source and Description \\
\hline $\begin{array}{l}\text { Regional } \\
\text { water-table } \\
\text { contour map }\end{array}$ & $\begin{array}{l}\text { Source: University of Nebraska-Lincoln Conservation and Survey Division } \\
\text { (http://snr.unl.edu/data/geographygis/index.aspx) } \\
\text { Description: Detailed digital contour map of the regional water table for the entire state of } \\
\text { Nebraska representative of spring } 1995 \text { conditions. Contours have an interval of } 50 \text { feet } \\
\text { (15.24 m). Considered the current best estimate of regional water-table elevations for the } \\
\text { modern period (A. Young, University of Nebraska Lincoln Conservation and Survey Division, } \\
\text { personal communication, } 2014 \text {; Szilagyi et al. 2013). This map was made using water-table } \\
\text { depth readings from observation wells and surface elevation records, and also topographic } \\
\text { characteristics of the land surface and elevations of surface water features from } 7.5 \text {-minute } \\
\text { U.S. Geological Survey (USGS) topographic maps (Summerside et al. 2001). Contours } \\
\text { were drawn on } 7.5 \text {-minute maps and then transferred to } 1: 250,000 \text { (1 } 1 \text { x } 2 \text {-degree) scale } \\
\text { work maps. However, in areas of extremely sparse observation wells, water-level elevation } \\
\text { points and contouring were plotted directly on the } 1 \times 2 \text {-degree maps (Summerside et al. } \\
\text { 2001). Accuracy of the contouring does not exist, but it is certainly less than } 3 \text {-m, as a } 3 \text {-m } \\
\text { contouring was possible in the Platte River Valley, and it is probably } 1 \text { m or less (Szilagyi } \\
\text { et al. 2013). }\end{array}$ \\
\hline
\end{tabular}




\begin{tabular}{|c|c|}
\hline Data Set & Source and Description \\
\hline $\begin{array}{l}\text { Digital } \\
\text { elevation } \\
\text { model (DEM) } \\
\text { of land surface } \\
\text { elevations }\end{array}$ & $\begin{array}{l}\text { Source: U.S. Geological Survey National Elevation Dataset (https://lta.cr.usgs.gov/NED) } \\
\text { Description: The National Elevation Dataset (NED) is a seamless data set with the best } \\
\text { available raster elevation data of the conterminous United States. All NED data are public } \\
\text { domain. NED data utilized had a resolution of } 1 / 3 \text { arc-second (about } 10 \mathrm{~m} \text { ). The NED is } \\
\text { derived from diverse source data that are processed to a common coordinate system and } \\
\text { unit of vertical measure. All elevation values are in meters and are referenced to the North } \\
\text { American Vertical Datum of } 1988 \text { (NAVD } 88 \text { ) in the conterminous United States. }\end{array}$ \\
\hline $\begin{array}{l}\text { Base of } \\
\text { principle } \\
\text { aquifer } \\
\text { contour map }\end{array}$ & $\begin{array}{l}\text { Source: University of Nebraska-Lincoln Conservation and Survey Division } \\
\text { (http://snr.unl.edu/data/geographygis/water.aspx) } \\
\text { Description: Digital contour map of the base of the principle aquifer for the entire state of } \\
\text { Nebraska. Originally published in } 1979 \text {. Contours have an interval of } 30.48 \mathrm{~m}(100 \mathrm{ft}) . \text { This } \\
\text { map was made based on geologist interpreted lithology information from boreholes. }\end{array}$ \\
\hline $\begin{array}{l}\text { Hydraulic } \\
\text { conductivity }\end{array}$ & $\begin{array}{l}\text { Source: U.S. Geological Survey (http://pubs.usgs.gov/ds/777/) } \\
\text { Description: Hydraulic properties database developed and synthesized for the High Plains } \\
\text { aquifer as part of the High Plains Groundwater Availability Study. Data are thickness- } \\
\text { weighted average estimates of hydraulic conductivity based on borehole lithology } \\
\text { interpretations. See the USGS report by Houston et al. (2013) for further information. }\end{array}$ \\
\hline $\begin{array}{l}\text { Net } \\
\text { groundwater } \\
\text { recharge }\end{array}$ & $\begin{array}{l}\text { Source: Szilagyi and Jozsa (2013) } \\
\text { Description: Spatially distributed high resolution (1.1-km) average net groundwater } \\
\text { recharge rates (GRn } \text { (Gpanning } 2000 \text { to } 2009 \text { for the entire state of Nebraska. Rates are } \\
\text { based on the difference between gridded precipitation (P) data (PRISM Climate Group } \\
2012 \text { ), and actual evapotranspiration (ET) data derived from MODerate-resolution Imaging } \\
\text { Spectroradiometer (MODIS) satellite temperature measurements and ancillary climate data } \\
\text { (maximum/minimum air temperature, dew-point temperature, and global radiation) (Szilagyi } \\
\text { et al. } 2011 \mathrm{a} \text { ). Where ET consistently exceeds P, negative values are obtained, and when } \\
\text { averaged over } 10 \text { years, these areas generally coincide with groundwater discharge zones } \\
\text { (i.e. lakes/wetlands) and irrigated or afforested areas. Because of the long-term average } \\
\text { (10-yr), these estimates are representative of quasi-steady-state conditions in the vadose } \\
\text { zone above the zero upward flux plane (cf. Brunner et al. 2004; Munch et al. 2013). The } \\
\text { basin-integrated recharge rates compare well in the NSH region with groundwater basin } \\
\text { runoff estimates and groundwater chloride mass balance at sites where land cover is } \\
\text { relatively homogeneous (Szilagyi et al. } 2011 \mathrm{~b} \text { ). In addition to having unprecedented spatial } \\
\text { resolution, this data set provides complete coverage and both positive and negative net } \\
\text { groundwater recharge fluxes, required for regional-scale groundwater modeling. }\end{array}$ \\
\hline $\begin{array}{l}\text { Land cover } \\
\text { survey map }\end{array}$ & $\begin{array}{l}\text { Source: University of Nebraska-Lincoln Center for Advanced Land Management } \\
\text { Information Technologies (CALMIT; http://snr.unl.edu/data/geographygis/land.aspx) } \\
\text { Description: Digital map of } 2005 \text { land cover for the entire state of Nebraska. Original } \\
\text { imagery was obtained from multiple Landsat } 5 \text { Thematic Mapper scenes covering the full } \\
\text { extent of Nebraska (see Dappen et al. 2007). Lakes, classified in the CALMIT Landsat land } \\
\text { cover data set as open water, are reported to have had the highest overall accuracy out of } \\
\text { the } 25 \text { land cover classes. Wetlands are described as follows (Dappen et al. 2007): } \\
\text { "Emergent wetlands, lands where saturation with water is the dominant factor determining } \\
\text { the nature of soil." Wetland training images used during supervised classification came from } \\
\text { the National Wetlands Inventory, which identified wetlands as permanently flooded, } \\
\text { intermittently exposed, or semi-permanently flooded. However, in most cases unsupervised } \\
\text { classification using only the spring date (May) of Landsat imagery proved most effective in } \\
\text { identifying wetland areas (Dappen et al. 2007). }\end{array}$ \\
\hline $\begin{array}{l}\text { Streamflow } \\
\text { gauge records } \\
\text { and baseflow } \\
\text { estimates }\end{array}$ & $\begin{array}{l}\text { Source: U.S. Geological Survey (http://waterdata.usgs.gov/nwis) and Nebraska Department } \\
\text { of Natural Resources (C. Lesmeister, NDNR, written communication, 2014) } \\
\text { Description: Daily streamflow records from six USGS and Nebraska Department of Natural } \\
\text { Resources (NDNR) gauges on streams located within the model domain were utilized } \\
\text { (Table S1 lists gauge information and baseflow estimates, and Fig. 4a in the main article } \\
\text { shows the locations of gauges). The methods used to estimate baseflow on the interior } \\
\text { streams are described in the following section. }\end{array}$ \\
\hline
\end{tabular}




\section{S2. Baseflow estimation}

Daily streamflow records from six USGS (http://waterdata.usgs.gov/nwis) and Nebraska Department of Natural Resources (NDNR) gauges (C. Lesmeister, NDNR, written communication, 2014) on the six major streams flowing out of the model domain were used (ESM Table S1, and Fig. 4a in the main article provide gauge information and locations). Estimates of daily baseflows were made from streamflow measurements through the application of an automated method described as a one-parameter digital filter (Lyne and Hollick 1979). An alpha parameter of 0.925 was used as it has been shown to provide realistic results when compared to manual hydrograph separation methods (Nathan and McMahon 1990). Bradley et al. (2013) provide details of the method.

Streamflow and baseflow averages for the period from 1 October 2000 to 30 September 2010 (overlapping with $\mathrm{GR}_{\mathrm{n}}$ estimates) were calculated using data from four of the six gauges. From the other two gauges, data for this period were unavailable, so average daily values were analyzed from the most recent 10-year period, 1 October 1985 to 30 September 1995, for the Dismal River at Dunning, and 1 October 1971 to 30 September 1981 for the Snake River above Merritt Reservoir (Table S1). The discharge of each stream is dominated by baseflow, as expected for this region (Bleed and Flowerday 1998; Chen et al. 2003), the cause of the nearly constant discharge and high baseflow index values of these streams ( $84 \%$ to $95 \%)$.

Estimates of average daily canal diversions were added to the streamflow gauge data to create diversion adjusted streamflow records. Adjusted baseflow values were then calculated by multiplying the adjusted streamflow records by the baseflow index of each stream. Estimates were based on surface-water rights data obtained from the online NDNR water rights archive (http://www.dnr.ne.gov/surface-water-rights). It was assumed that diversion rates equal the surface-water right amount applied over $20 \%$ of the year. This adjustment was considered to be reasonable since it brought the longterm average in line with the average streamflows during parts of the year not affected by canal diversions. Gauges affected by this adjustment include Blue Creek, Birdwood Creek, and the North Loup River (Fig. 1 and Fig. $4 a$ in the main article show stream and gauge locations, respectively). Information and data on adjusted baseflow, and baseflow index $(\mathrm{BFI})$, are presented in ESM Table S1. 
Table S1 Stream gauge information and estimates of baseflow and baseflow index (BFI) for streams exiting the Nebraska Sand Hills groundwater model domain

\begin{tabular}{lccccc}
\hline Station & $\begin{array}{c}\text { Station } \\
\text { number }\end{array}$ & $\begin{array}{c}\text { Beginning } \\
\text { year for } \\
\text { baseflow } \\
\text { calculations }\end{array}$ & $\begin{array}{c}\text { Ending } \\
\text { year for } \\
\text { baseflow } \\
\text { calculations }\end{array}$ & $\begin{array}{c}\text { Average } \\
\text { annual } \\
\text { baseflow } \\
\left(\mathbf{1 0}^{\mathbf{6}} \mathbf{~ m}^{\mathbf{3}} \mathbf{d}^{-1}\right)\end{array}$ & $\begin{array}{c}\text { Ratio of } \\
\text { baseflow to total } \\
\text { streamflow (BFI) }\end{array}$ \\
\hline $\begin{array}{l}\text { Blue Creek near } \\
\text { Lewellen }\end{array}$ & 06687000 & 2000 & 2010 & $0.187^{\mathrm{a}}$ & 0.88 \\
$\begin{array}{c}\text { Blue Creek near } \\
\text { Hershey }\end{array}$ & 06692000 & 2000 & 2010 & $0.369^{\mathrm{b}}$ & 0.95 \\
$\begin{array}{c}\text { Dismal River at } \\
\text { Dunning }\end{array}$ & 06776500 & 1985 & 1995 & 0.814 & 0.95 \\
$\begin{array}{c}\text { Middle Loup River at } \\
\text { Dunning }\end{array}$ & 06775500 & 2000 & 2010 & 1.085 & 0.95 \\
$\begin{array}{c}\text { North Loup River at } \\
\text { Taylor }\end{array}$ & 06786000 & 2000 & 2010 & $1.268^{\mathrm{c}}$ & 0.84 \\
$\begin{array}{c}\text { Snake River above } \\
\text { Merritt Reservoir }\end{array}$ & 06459200 & 1971 & 1981 & 0.462 & 0.94 \\
\hline
\end{tabular}

${ }^{a}$ Values of baseflow have been increased by $27.2 \%$ to account for surface water diversions

${ }^{\mathrm{b}}$ Values of baseflow have been increased by $6.1 \%$ to account for surface water diversions

${ }^{c}$ Values of baseflow have been increased by $13.2 \%$ to account for surface water diversions 


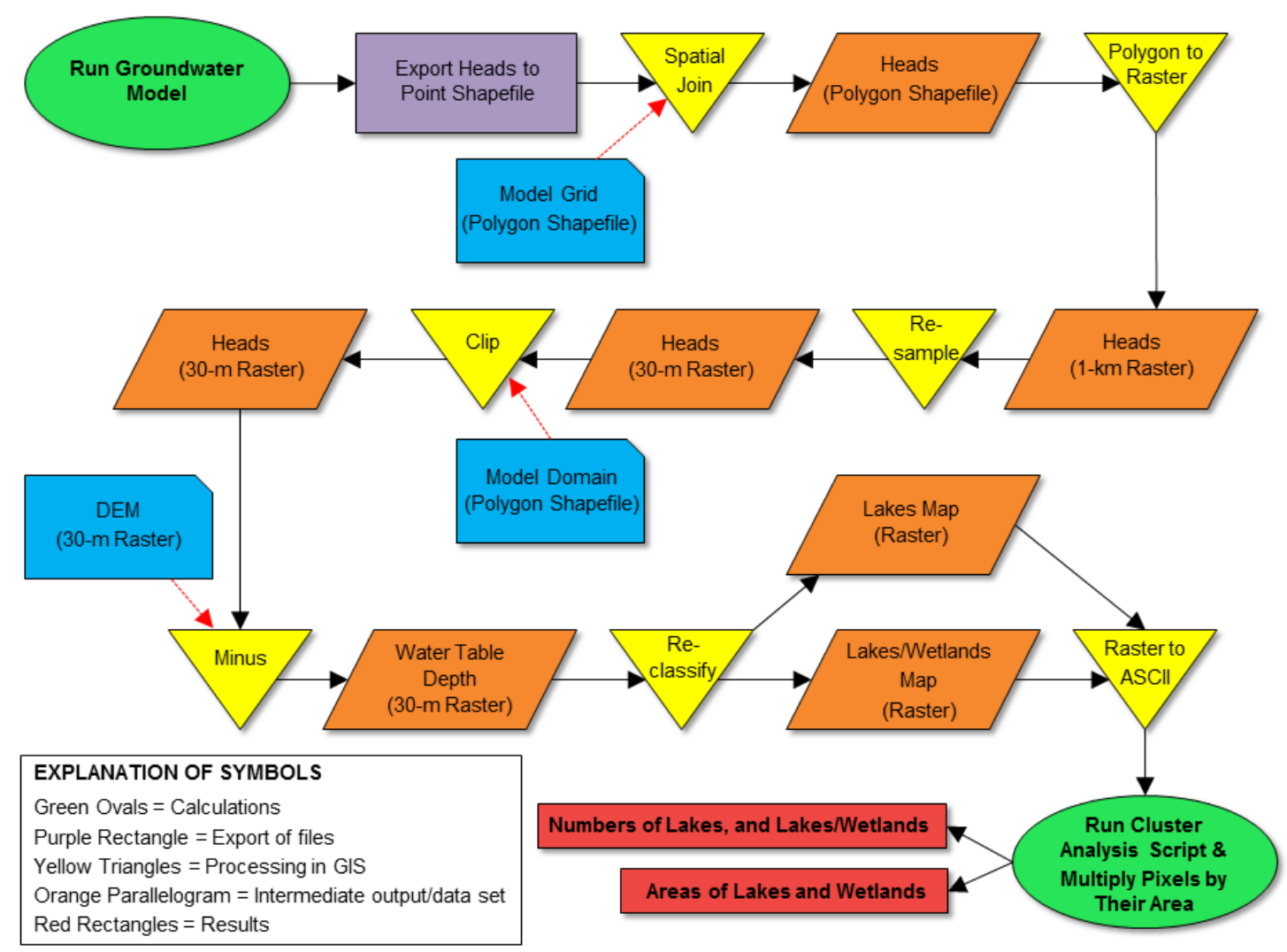

Fig. S1 Flowchart of processing steps taken to create maps and calculate areas and numbers of lakes and wetlands

\section{S3. Further details of model calibration}

Calibration of the Nebraska Sand Hills groundwater model consisted of manual trialand-error, and automatic adjustment of parameters to improve agreement between observed (or estimated) and simulated values from a set of quantitative calibration targets, and qualitative targets. Table S2 lists the order of the six key calibration steps involved in calibration. These steps are detailed further as follows:

1. Prior to automatic calibration, manual adjustments were made to $K$ within 29 zones having initial values from the means calculated based on borehole lithology (Fig. S2; USGS hydrogeologic data from the High Plains aquifer [Houston et al. 2013; Peterson et al. 2008]). After the model run, the match with the regional water-table contours was deemed unsatisfactory.

2. The pilot point method (Doherty et al. 2010) was used to perform PEST optimization of $K$, while maintaining original $G R_{n} .1571$ pilot points were used, with uniform 5-km spacing across the model domain (Fig. S3a). Initial $\mathrm{K}$ at pilot points were the same as those presented in Step 1 (zone averages). Grid cells with head targets were 
assigned elevations from the DEM-adjusted interpolation of the water-table map, for 7937 targets (20\% of active cells) (Fig. S3b).

3. Linear leakance parameter of Drains and Rivers from USGS modeling studies by Peterson et al. (2008) and Stanton et al. (2010) was adjusted manually and ultimately increased by a factor of two-slightly affecting heads near streams. Calibrated values of the leakance parameter ranged from 0.06 to $19.2 \mathrm{~m}^{2} \mathrm{~d}^{-1} \mathrm{~m}^{-1}$.

4. Drain elevations were reduced by as much as $2 m$ along some streams, and Constant Head elevations along the North Platte River were decreased by $1 \mathrm{~m}$ in order to lower hydraulic heads locally. These changes were substantially less influential to the simulation than the PEST adjustments of $K$. The adjustments to leakance and stage were negligible relative to the changes made to $K$ with PEST (Step 2).

5. Manual adjustments to $G R_{n}$ were performed. This was necessary because initial automatic parameter estimation yielded a number of grid cells with $K$ falling outside the established limits-range from 1 to $36 \mathrm{~m} \mathrm{~d}^{-1}$ reflected by regional geology, previous regional groundwater modeling, and $K$ estimates from borehole lithology (Table S3). Values of $G R_{n}$ were adjusted by adding or subtracting as much as 20 $\mathrm{mm} \mathrm{yr} \mathrm{r}^{-1}$ to/from the initial estimates from remote sensing (Fig. 4a of the main article) uniformly within 127 20x20-km zones (Fig. S4). The zones were developed on a uniform grid, and the choice to use 127 zones was both a pragmatic one, allowing a somewhat limited number of zones, and largely preserving the $G R_{n}$ spatial distribution originally determined with a 1-km resolution (from MODIS); a similar calibration approach was used by Feinstein et al. (2010).

6. The final PEST run on $\mathrm{K}$ was performed using a Tikhonov-regularization process to constrain the inversion (Tikhonov and Arsenin 1977) and the lower and upper limits to $K$ of $1 \mathrm{~m} \mathrm{~d}^{-1}$ and $36 \mathrm{~m} \mathrm{~d}^{-1}$ were applied, as well as the adjusted $G R_{n}$ values. Initial $K$ values were those assigned as means to 29 zones based on borehole lithology. Same as the first PEST run, 1571 pilot points were used, with 7937 head targets. 
Table S2 Key steps involved in model calibration

\begin{tabular}{|c|c|c|}
\hline $\begin{array}{l}\text { Calibrati } \\
\text { on step }\end{array}$ & $\begin{array}{c}\text { Parameter } \\
\text { updated }\end{array}$ & Description \\
\hline 1 & $\begin{array}{l}\text { Hydraulic } \\
\text { conductivity } \\
(K)\end{array}$ & $\begin{array}{l}\text { Hydraulic conductivity map produced and manual } \\
\text { adjustments made-29 irregular zones; initial values } \\
\text { based on mean estimates from } 261 \text { boreholes; original } \\
\mathrm{GR}_{\mathrm{n}} \text { maintained }\end{array}$ \\
\hline 2 & $\begin{array}{l}\text { Hydraulic } \\
\text { conductivity } \\
(K)\end{array}$ & $\begin{array}{l}\text { Hydraulic conductivity adjusted using PEST-1571 pilot } \\
\text { points }(5 \times 5-\mathrm{km}) \text {, and } 7937 \text { head targets; no regularization } \\
\text { or upper and lower limits applied; original } \mathrm{GR}_{\mathrm{n}} \\
\text { maintained }\end{array}$ \\
\hline 3 & $\begin{array}{l}\text { Linear } \\
\text { leakance }\end{array}$ & $\begin{array}{l}\text { Linear leakance (conductance divided by length of } \\
\text { stream) of portions of select interior streams increased } \\
\text { by a factor of two }\end{array}$ \\
\hline 4 & $\begin{array}{l}\text { Stream/river } \\
\text { stage } \\
\text { elevation }\end{array}$ & $\begin{array}{l}\text { Drain elevations of portions of select interior streams } \\
\text { reduced by as much as } 2 \mathrm{~m} \text {, and Constant Head } \\
\text { elevations along a portion of the North Platte River } \\
\text { (southern boundary) reduced by } 1 \mathrm{~m}\end{array}$ \\
\hline 5 & $\begin{array}{l}\text { Net } \\
\text { groundwater } \\
\text { recharge } \\
\left(\mathrm{GR}_{\mathrm{n}}\right)\end{array}$ & $\begin{array}{l}\text { Net groundwater recharge adjusted manually-127 } \\
\text { uniform zones }(20 \times 20-\mathrm{km}) \text { on the basis of constraining } K \\
\text { to within pre-defined range from } 1 \text { to } 36 \mathrm{~m} \mathrm{~d}^{-1} \text {; adjusted } \\
\text { up or down by } 0 \text { to } 20 \mathrm{~mm} \mathrm{yr}^{-1}\end{array}$ \\
\hline 6 & $\begin{array}{l}\text { Hydraulic } \\
\text { conductivity } \\
(K)\end{array}$ & $\begin{array}{l}\text { Hydraulic conductivity adjusted using PEST with } \\
\text { regularization and limits-1571 pilot points ( } 5 \times 5-\mathrm{km} \text { ), and } \\
7937 \text { head targets; Tikhonov regularization of } K \text { with } \\
\text { initial values from Step } 1 \text { ( } 29 \text { zones, } 261 \text { boreholes); } \\
\text { limits of } 1 \text { and } 36 \mathrm{~m} \mathrm{~d}^{-1} \text { applied; adjusted } \mathrm{GR}_{\mathrm{n}} \text { applied }\end{array}$ \\
\hline
\end{tabular}




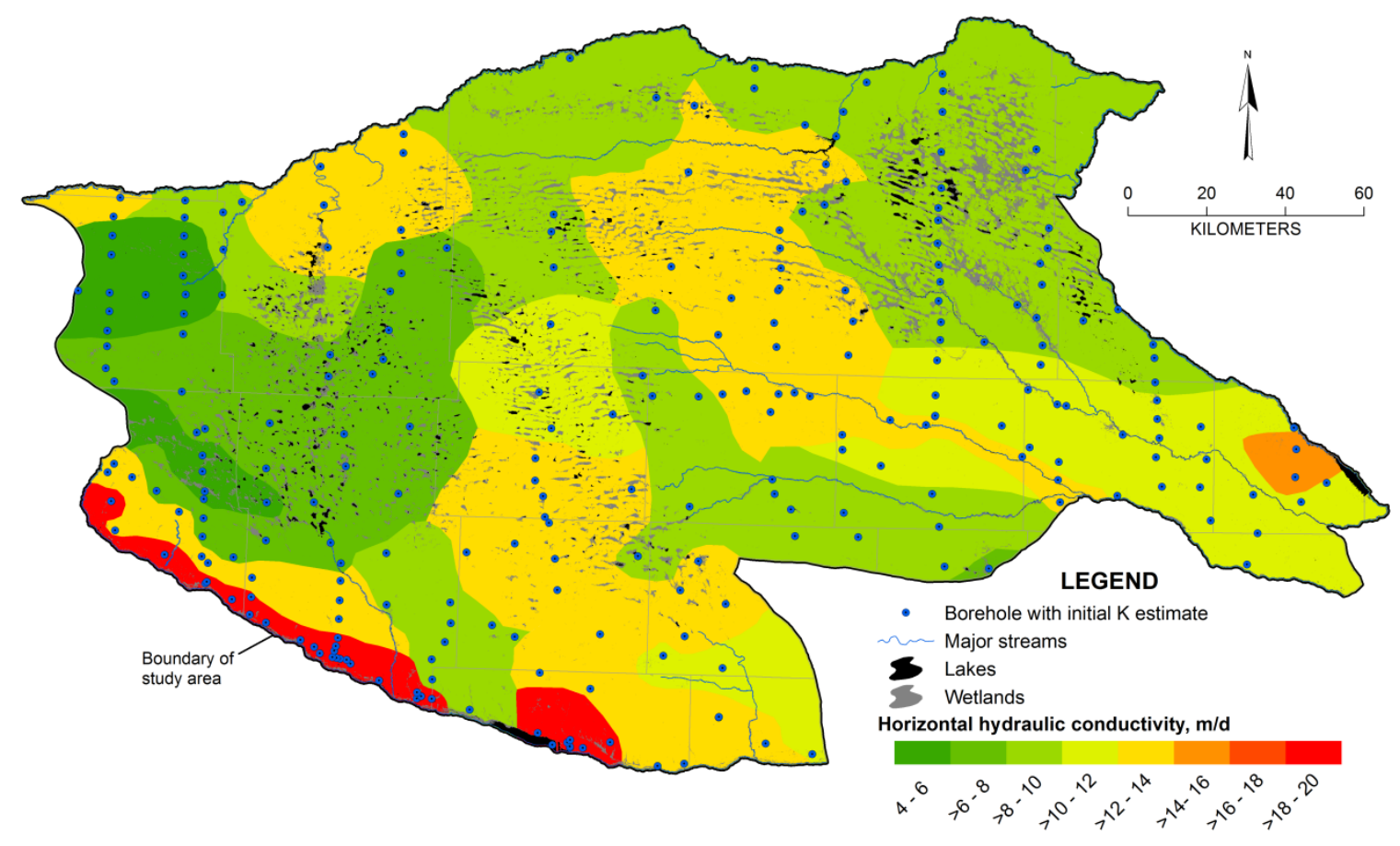

Fig. S2 Zones and average values of initial thickness-weighted average hydraulic conductivity, based on borehole lithology, including borehole locations, lakes, wetlands, and major streams 


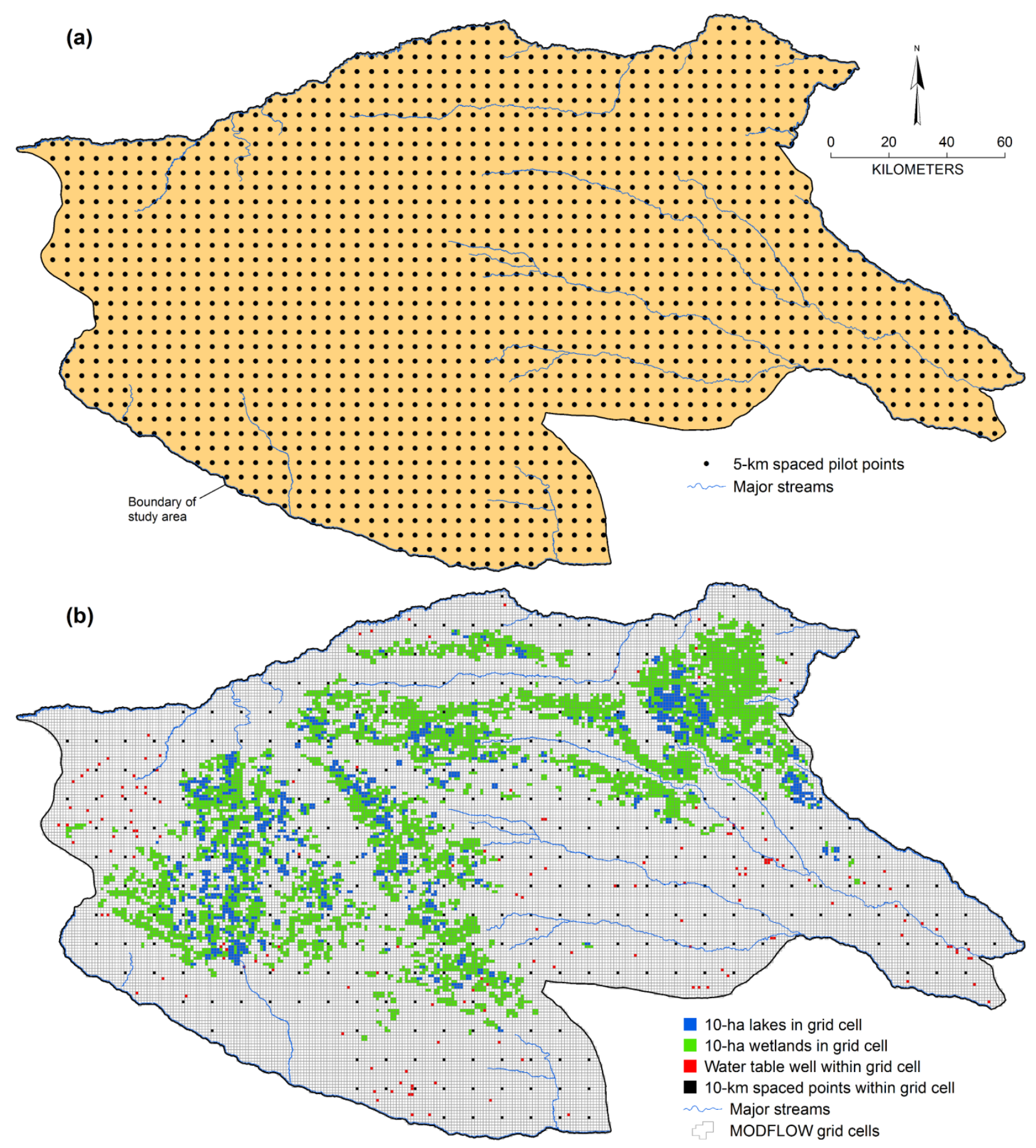

Fig. S3 Pilot points spaced uniformly at 5-km (a); and grid cells with head targets used during automatic (PEST) model calibration 


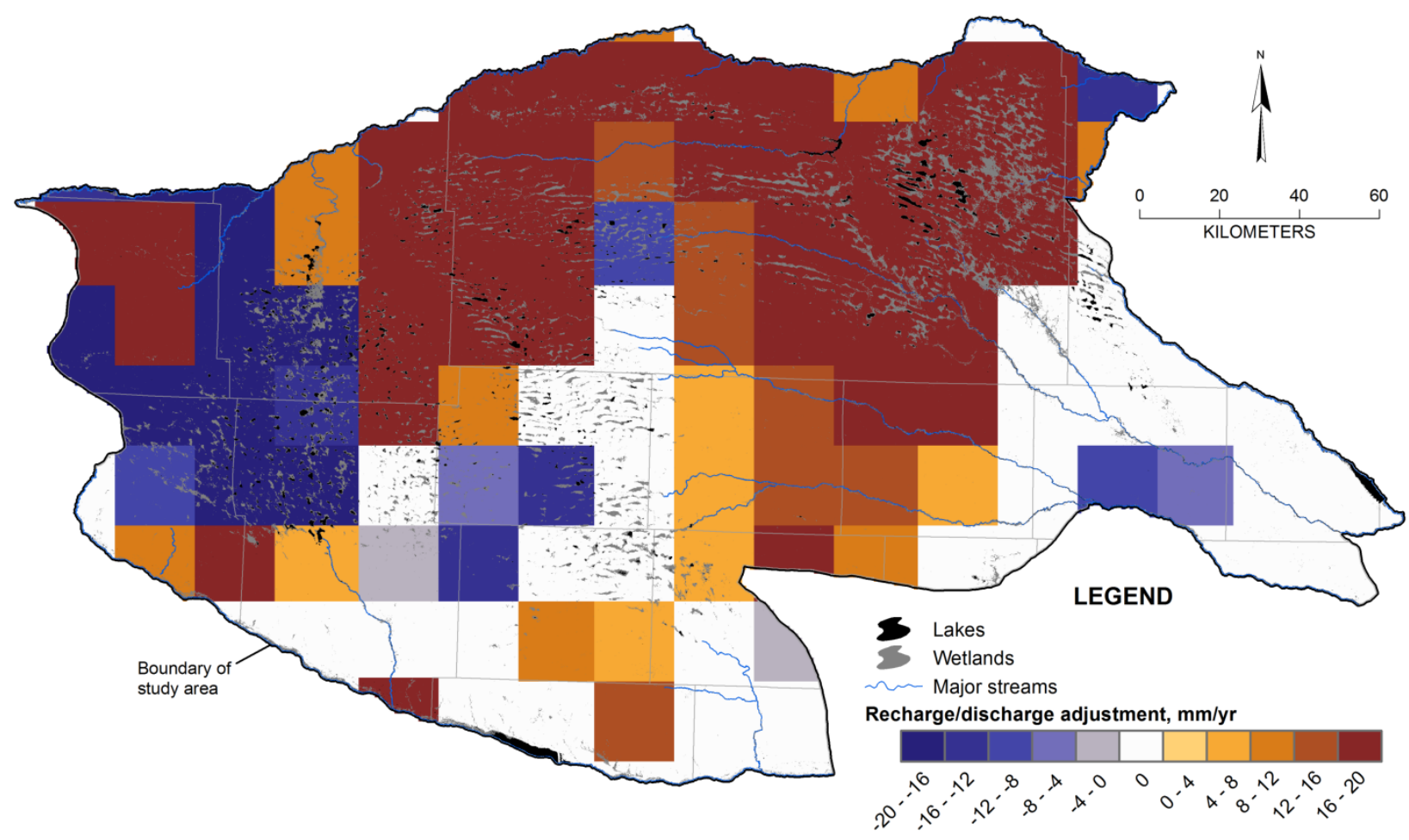

Fig. S4 Adjustments made to net groundwater recharge rates during calibration; positive values are an increase in net recharge, and negative values are a decrease in net recharge 


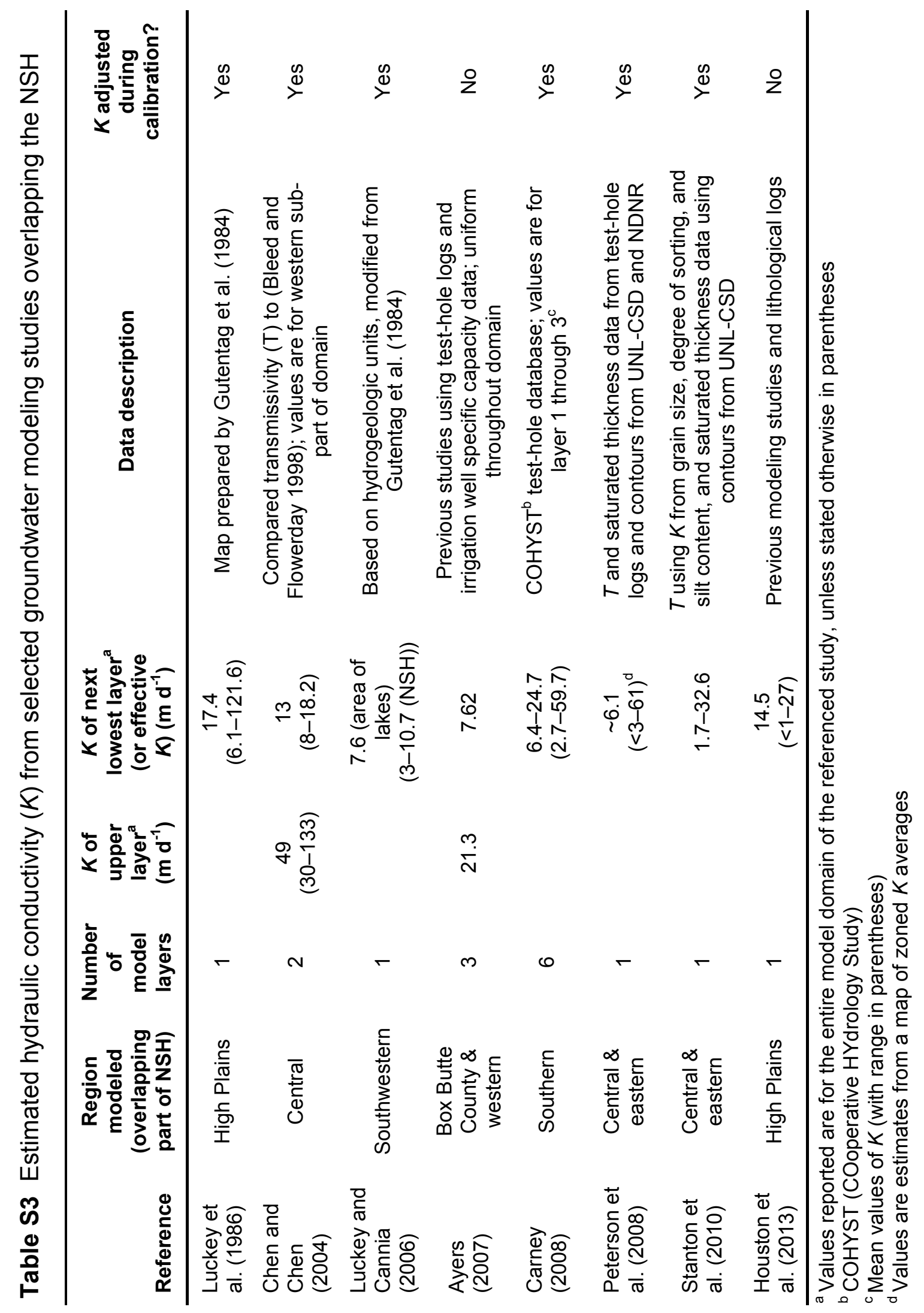




\section{S4. Areas of mismatch between observed and simulated lakes and wetlands}

Observed lakes and wetlands were compared with those resulting from the GIS terrain analysis described in Section 'Groundwater flow modeling: Lakes and wetlands' of the main article. While the calibration of modeled heads to estimated groundwater levels was very accurate (RMSE $=2.8 \mathrm{~m}$ ), and much of the domain displays a satisfactory agreement between observed and simulated lakes and wetlands, there are some notable parts of the domain in which this is not the case (i.e. spatial bias); the areas are identified on Fig. S5. The overall difference between combined areas of lakes and wetlands in these areas of mismatch were calculated in GIS using the Zonal Statistics tool to understand how much these areas contribute to the total discrepancy between combined lake and wetland areas. The differences between observed and simulated lake and wetland areas are listed in Table S4 corresponding with areas shown on Fig. S5. Generally, these areas of mismatch contribute relatively small amounts to the overall discrepancy between total observed and simulated combined lake and wetland areas (10.9\% overestimate). However, one area of concern is portions of the far northeastern part of the domain, in which a difference of $94 \mathrm{~km}^{2}$ of combined lake and wetland areas were not simulated with the calibrated model.

Ways in which the overall match between observed and simulated lakes and wetlands may be improved in the future are associated with carrying out a more robust calibration effort, which could include: 1) considering structural uncertainty (i.e. a multi-model approach with various aquifer thicknesses or boundary condition types); 2) allowing more parameters to be varied with PEST, such as head-dependent boundary parameters and groundwater recharge, and perhaps adding a censored target type that penalizes the objective function if hydraulic heads exceed land surface elevation in locations where there are not any observed lakes or wetlands; and 3) increasing the density of pilot points in areas of the model with high-density head target coverage, and perhaps utilizing different pilot-point placement for varying different parameters (such as Drain conductance).

Table S4 Areas of mismatch between observed and simulated lake and wetland areas and their relative contribution as compared to the total area observed in the NSH (excluding a 1-km buffer around major streams) ${ }^{\mathrm{a}, \mathrm{b}}$

\begin{tabular}{ccccc}
\hline $\begin{array}{c}\text { Area of } \\
\text { mismatch }\end{array}$ & $\begin{array}{c}\text { Observed } \\
(\mathbf{2 0 0 5} \text { Landsat } \\
\text { survey) } \\
\left.\mathbf{( k m}^{2}\right)\end{array}$ & $\begin{array}{c}\text { Simulated } \\
\left.\mathbf{( k m}^{\mathbf{2}}\right)\end{array}$ & $\begin{array}{c}\text { Difference } \\
\left.\mathbf{( k m}^{\mathbf{2}}\right)\end{array}$ & $\begin{array}{c}\text { Percent of } \\
\text { observed lake } \\
\text { and wetland } \\
\text { areas (\%) }\end{array}$ \\
\hline 1 & 4.90 & 12.54 & -7.64 & -0.4 \\
2 & 6.38 & 45.31 & -38.93 & -2.1 \\
3 & 24.80 & 0.47 & 24.33 & 1.3 \\
4 & 44.59 & 5.53 & 39.06 & 2.1 \\
5 & 97.23 & 2.87 & 94.36 & 5.0 \\
\hline
\end{tabular}

${ }^{a}$ Areas are numbered according to Fig. S5

${ }^{b}$ Observed lakes and wetlands from CALMIT 2005 Landsat survey (Dappen et al. 2007) 


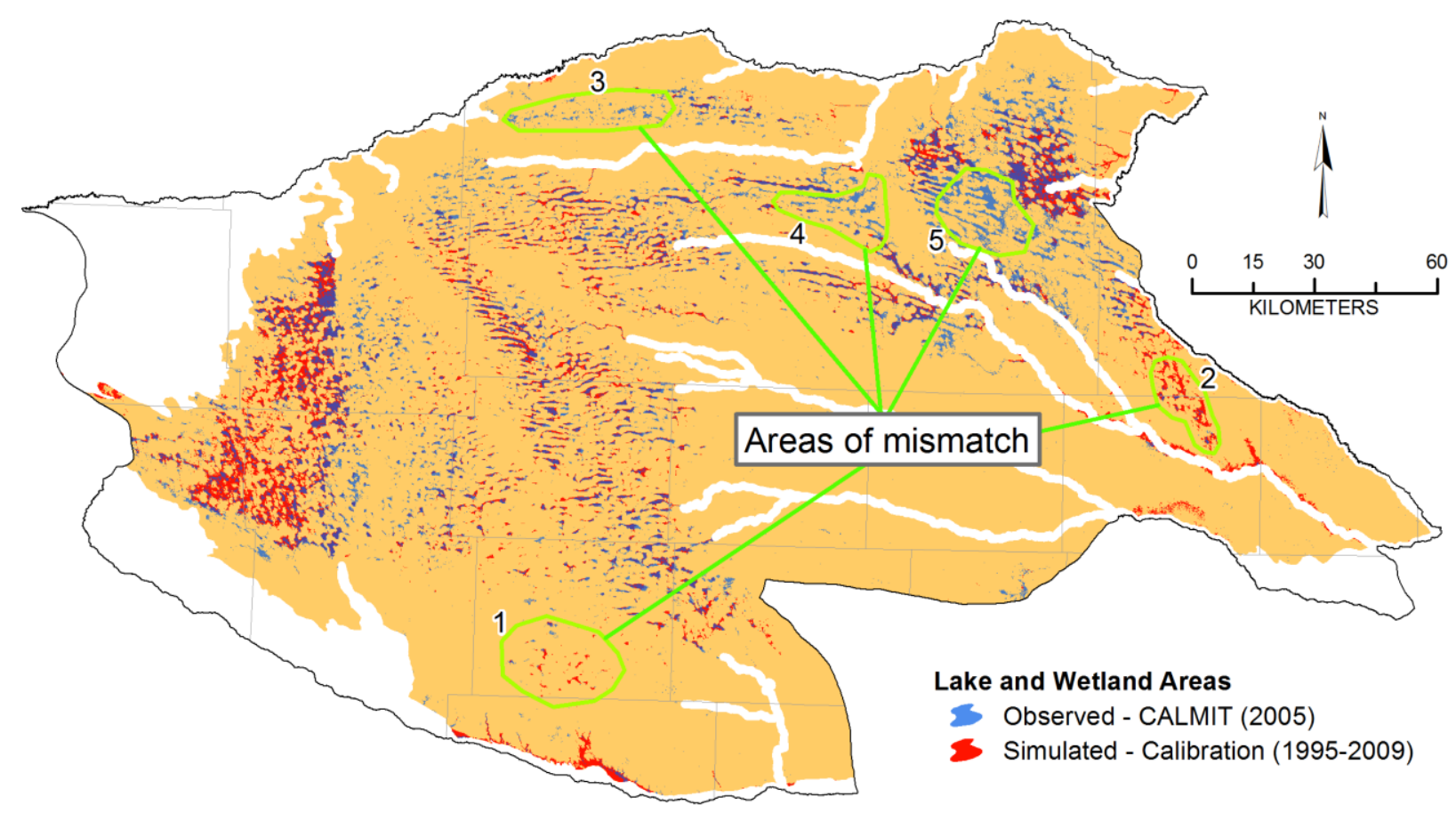

Fig. S5 Areas of mismatch identified between observed and simulated lakes and wetlands

\section{ESM References}

Ayers JF (2007) Box Butte County-Niobrara River numerical groundwater flow model. Project Completion Report. Available at https://dnr.nebraska.gov/sites/dnr.nebraska.gov/files/doc/waterplanning/niobrara/publications/Box-Butte ModelProjectCompletionReport.pdf. Cited 25 October 2017

Bleed AS, Flowerday CA (eds.) (1998) An atlas of the Sand Hills. $3^{\text {rd }}$ edn. Conservation and Survey Division, University of Nebraska-Lincoln, Lincoln, NE, 260 pp

Bradley JR, Kuntz T, Luckey RR (2013) Hydrograph separation methods used to estimate groundwater discharge for assistance in calibration of the Western Water Use Model. Nebraska Department of Natural Resources. Available at https://dnr.nebraska.gov/sites/dnr.nebraska.gov/files/doc/waterplanning/BaseflowReport2013.pdf. Cited 25 October 2017

Brunner P, Bauer P, Eugster M, Kinzelbach W (2004) Using remote sensing to regionalize local precipitation recharge rates obtained from the Chloride Method. J Hydrol 294(4):241-250. doi:10.1016/j.jhydrol.2004.02.023 
Carney CP (2008) Groundwater flow model of the Central Model Unit of the Nebraska Cooperative Hydrology Study (COHYST) area. COHYST Technical Report, Lincoln, NE. Available at http://cohyst.nebraska.gov/adobe/dc012CMU GFMR 081224.pdf. Cited 25 October 2017

Chen X, Chen X (2004) Simulating the effects of reduced precipitation on ground water and streamflow in the Nebraska Sand Hills. J American Water Resour Assoc 40(2):419-430. doi:10.1111/j.1752-1688.2004.tb01040.x

Chen X, Chen X, Rowe C, Hu Q, Anderson M (2003) Geological and climatic controls on streamflows in the Nebraska Sand Hills. J American Water Resour Assoc 39(1):217-228. doi:10.1111/j.1752-1688.2003.tb01573.x

Dappen P, Merchant J, Ratcliffe I, Robbins C (2007) Delineation of 2005 land use patterns for the state of Nebraska Department of Natural Resources. Final Rep. Center for Advanced Land Management Information Technologies. University of Nebraska-Lincoln, Lincoln, NE. Available at https://calmit.unl.edu/pdf/2005 Landuse FinalReport.pdf. Cited 25 October 2017

Doherty JE, Fienen MN, Hunt RJ (2010) Approaches to highly parameterized inversion: Pilot-point theory, guidelines, and research directions. US Geol Sur Sci Invest Rep 2010-5168. USGS, Reston, VA, $36 \mathrm{pp}$

Feinstein DT, Dunning CP, Juckem PF, Hunt RJ (2010) Application of the Local Grid Refinement package to an inset model simulating the interactions of lakes, wells, and shallow groundwater, northwestern Waukesha County, Wisconsin. US Geol Sur Sci Invest Rep 2010-5214. USGS, Reston, VA, 30 pp

Gutentag ED, Heimes FJ, Krothe NC, Luckey RR, Weeks JB (1984) Geohydrology of the High Plains aquifer in parts of Colorado, Kansas, Nebraska, New Mexico, Oklahoma, South Dakota, Texas, and Wyoming. US Geol Surv Prof Pap 1400-B. USGS, Reston, VA, $63 \mathrm{pp}$

Houston NA, Gonzales-Bradford SL, Flynn AT, Qi SL, Peterson SM, Stanton JS, Ryter DW, Sohl TL, Senay GB (2013) Geodatabase compilation of hydrogeologic, remote sensing, and water-budget-component data for the High Plains aquifer, 2011. US Geol Sur Data Ser 777. USGS, Reston, VA, $12 \mathrm{pp}$. Available at http://pubs.usgs.gov/ds/777/. Cited 26 October 2013

Luckey RR, Gutentag ED, Heimes FJ, Weeks JB (1986) Digital simulation of groundwater flow in the High Plains aquifer in parts of Colorado, Kansas, Nebraska, New Mexico, Oklahoma, South Dakota, Texas, and Wyoming. US Geol Sur Prof Pap 1400-D. USGS, Reston, VA, $57 \mathrm{pp}$

Luckey RR, Cannia JC (2006) Groundwater flow model of the Western Model Unit of the Nebraska Cooperative Hydrology Study (COHYST) area. COHYST Technical Report, Lincoln, NE. Available at ftp://ftp.dnr.nebraska.gov/Pub/cohystftp/cohyst/model reports/WMU Documentation 060519.pdf. Cited 25 October 2017

Lyne VD, Hollick M (1979) Stochastic time-variable rainfall-runoff modeling. Hydrol and Water Resour Symp. Institution of Engineers Australia, Perth, AUS, p. 89-92

Munch Z, Conrad JE, Gibson LA, Palmer AR, Hughes D (2013) Satellite earth observation as a tool to conceptualize hydrogeological fluxes in the Sandveld, South Africa. Hydrogeol J 21(5):1053-1070. doi:10.1007/s10040-013-1004-1 
Nathan RJ, McMahon TA (1990) Evaluation of automated techniques for baseflow and recession analysis. Water Resour Res, 26(7):1465-1473. doi:10.1029/WR026i007p01465

Peterson SM, Stanton JS, Saunders AT, Bradley JR (2008) Simulation of ground-water flow and effects of ground-water irrigation on base flow in the Elkhorn and Loup River basins, Nebraska. US Geol Sur Sci Invest Rep 2008-5143. USGS, Reston, $\mathrm{VA}, 66 \mathrm{pp}$

PRISM (Parameter-elevation Regressions on Independent Slopes Model) Climate Group (2012) Oregon State University climate data. Available at http://prism.oregonstate.edu. Cited 10 October 2012

Stanton JS, Peterson SM, Fienen MN (2010) Simulation of groundwater flow and effects of groundwater irrigation on stream base flow in the Elkhorn and Loup River basins, Nebraska, 1895-2055: phase two. US Geol Sur Sci Invest Rep 2010-5149. USGS, Reston, VA, $78 \mathrm{pp}$

Summerside S, Ponte M, Dreeszen VH, Hartung SL, Khisty MJ, Szilagyi J (2001) Update and revision of regional $1 \times 2$ degree water-table configuration maps for the state of Nebraska. Conservation and Survey Division, University of Nebraska, Lincoln, NE, $14 \mathrm{pp}$

Szilagyi J, Jozsa J (2013) MODIS-aided statewide net groundwater-recharge estimation in Nebraska. Groundwater 51(5):735-744. doi:10.1111/j.1745-6584.2012.01019.x

Szilagyi J, Jozsa J, Kovacs A (2011b) A calibration-free evapotranspiration mapping (CREMAP) technique. In: Labedzki L (ed.), Evapotranspiration. InTech, Rijeka, Croatia, p. 257-274

Szilagyi J, Zlotnik VA, Gates J, Jozsa J (2011a) Mapping mean annual groundwater recharge in the Nebraska Sandhills, USA. Hydrogeol J 19(8):1503-1513. doi:10.1007/s10040-011-0769-3

Szilagyi J, Zlotnik VA, Jozsa J (2013) Net recharge vs. depth to groundwater relationship in the Platte River Valley of Nebraska, United States. Groundwater 51(6):945-951. doi:10.1111/gwat.12007.

Tikhonov AN, Arsenin VY (1977) Solutions of ill-posed problems. V.H. Winston and Sons, Washington DC 